\title{
Risks, costs and labour markets: explaining cross-national patterns of far right party success in European Parliament elections
}

Article

Accepted Version

Halikiopoulou, D. and Vlandas, T. (2016) Risks, costs and labour markets: explaining cross-national patterns of far right party success in European Parliament elections. Journal of Common Market Studies, 54 (3). pp. 636-655. ISSN 14685965 doi: https://doi.org/10.1111/jcms.12310 Available at https://centaur.reading.ac.uk/40854/

It is advisable to refer to the publisher's version if you intend to cite from the work. See Guidance on citing.

To link to this article DOI: http://dx.doi.org/10.1111/jcms.12310

Publisher: Wiley

All outputs in CentAUR are protected by Intellectual Property Rights law, including copyright law. Copyright and IPR is retained by the creators or other copyright holders. Terms and conditions for use of this material are defined in the End User Agreement. 


\section{CentAUR}

Central Archive at the University of Reading

Reading's research outputs online 


\title{
Risks, Costs and Labour Markets: Explaining cross-national patterns of far right party success in European Parliament Elections
}

\author{
Daphne Halikiopoulou and Tim Vlandas ${ }^{1}$
}

\section{** This paper has been accepted for publication in JCMS. Please contact authors for citation details**}

What is the effect of the economy on far right party support? On the one hand, economic factors are often seen to be shifting the attitudes and preferences of voters towards such parties (Lipset 1960; Betz 1994). These explanations differ in scope and in particular in whether the preference for the far right is the product of objective characteristics or subjective attitudes. But all these theories suggest that indicators such as unemployment, low income, and more generally deprivation and expectation of deprivation create conditions favourable to the rise of far right parties. This framework has been used to explain both the rise of the fascist parties that emerged during the interwar period, and the radical right variants that have re-emerged in Europe since the 1990 's. On the other hand, other work has shown that economic stress is not necessarily causally linked to far right party support (Mudde 2010; Art 2011). An increasing number of studies has found that ethnic threats have a greater impact than economic threats (Ivarsflaten 2008; Lucassen and Lubbers 2012) indicating that national identity is more of a driving force of far right party support than economic interest (Sniderman and Hagendoorn 2007).

Most of these studies, however, either employ small $\mathrm{N}$ methods, focusing on one or few cases thereby limiting the potential for generalizability or large $\mathrm{N}$ methods focusing on individual level 
voting patterns. But what is the impact of the economy on cross-national patterns of far right party support in the EU? While much attention has been given to the effect of unemployment in previous literature, few studies have addressed the question of variation at the country level. An exception is Arzheimer (2009). This study investigates cross-national variation in Western Europe before Eastern enlargement, combining system-level variables with individual sociodemographic and attitudinal data in the period between 1980 and 2002 and including in the analysis cases where the far right performed poorly.

In this paper, we test the effect of the economy on macro-level patterns of far right party support in European Parliament (EP) elections. The latter may described as 'second-order national contests' (Reif and Schmitt 1980; Van der Eijk and Franklin 1996), i.e. secondary to national elections, but still national rather than European contests (Hix and Marsh 2007). While we may expect the second order effect to inflate support for smaller parties, this does not explain the significant variations we observe in terms of support for far right parties across the EU. Given standardization in terms of time and electoral system, EP elections offer a good platform from which to explore these macro level patterns of far right party support from a comparative perspective: how may we explain cross-national variations; and do existing explanations apply at the EP level?

EP elections show interesting cross-national variation in far right party support that is not prima facie consistent with a simple demand- side model, which therefore calls for a systematic comparative study. In the 2014 'earthquake' EP elections, the peripheral countries that

\footnotetext{
${ }^{1}$ The authors' names have been listed in alphabetical order. Both authors have contributed equally to this work.
} 
experienced the most severe economic crises such as Portugal, Ireland, Italy, Greece and Spain clearly displayed varying far right party success: while in Greece the far right Golden Dawn (GD) experienced a significant rise, in Spain National Democracy (ND) and Spain 2000, and in Portugal the National Renovator Party (PNR) did not; in Ireland there is no far right party; and in Italy the Northern League (LN) declined. There are also significant variations within and between countries that did not experience comparable crisis conditions, including France, the UK, Sweden, Denmark and Finland. Unemployment levels vary across Europe (see Figure 1), showing again no correlation: countries with highest unemployment rates including Spain did not witness a rise in far right party support, while countries with low unemployment levels did. Economic malaise is not necessarily present in all cases where we observe the rise of the far right (although it is correlated in some cases such as Greece). The correlation between unemployment and far right party support for the 2014 election is low and not statistically significant.

This calls for a more thorough test of the impact of economic factors on far right party support. Building on existing demand side literature that focuses on the economy (Swank and Betz 2003; Kitschelt with McGann 1995; Kriesi et al 2006), this paper conceptualises the effect of labour market insecurity that unemployment creates in terms of costs and risks. Costs refer to the material penalty that unemployment entails while risks capture the greater fear of unemployment that may arise in the employed population when national unemployment rises. Both costs and risks are partly determined by the national unemployment rate and partly by labour market institutions. Cost most obviously depends on the economic condition - the national unemployment - but also on the extent to which unemployment is 'compensated' by labour market institutions. Similarly, unemployment risks determine the likelihood of bearing that cost 
and are therefore dependent on labour market regulations. Thus, we expect unemployment to be associated with higher far right support only in countries where unemployment is very costly because of low unemployment benefits or in countries where unemployment increases the risk of employed workers becoming unemployed because of low dismissal regulations.

We test these expectations using panel data regression analysis on a dataset comprising three EP elections covering 28 European countries and capturing three time periods: before, during and after the financial crisis. Our results confirm that unemployment by itself is not statistically significant when controlling for all other relevant factors. However, demand side economic factors do matter, but in a more complex way: where unemployment benefits and dismissal regulations are high, unemployment has no effect, but where either one of them is low, unemployment leads to higher far right support.

This paper contributes to existing literature in two ways. First, empirically, this paper provides a macro level test of the expectations from the demand side economic literature and explains the variation in EP election results. Second, we show that far right party support is fuelled less strongly by national unemployment levels in case of specific welfare state institutional arrangements.

This paper enfolds as follows. In the next section, we classify far right parties and review previous literature on demand-side explanations of far right party support. We then derive a number of hypotheses concerning the impact of unemployment on far right party support. Using statistical analysis we then test these hypotheses and present our results. The last section concludes with some implications for future research avenues. 
Figure 1: Far right parties in 2014 EP elections and 2013 unemployment

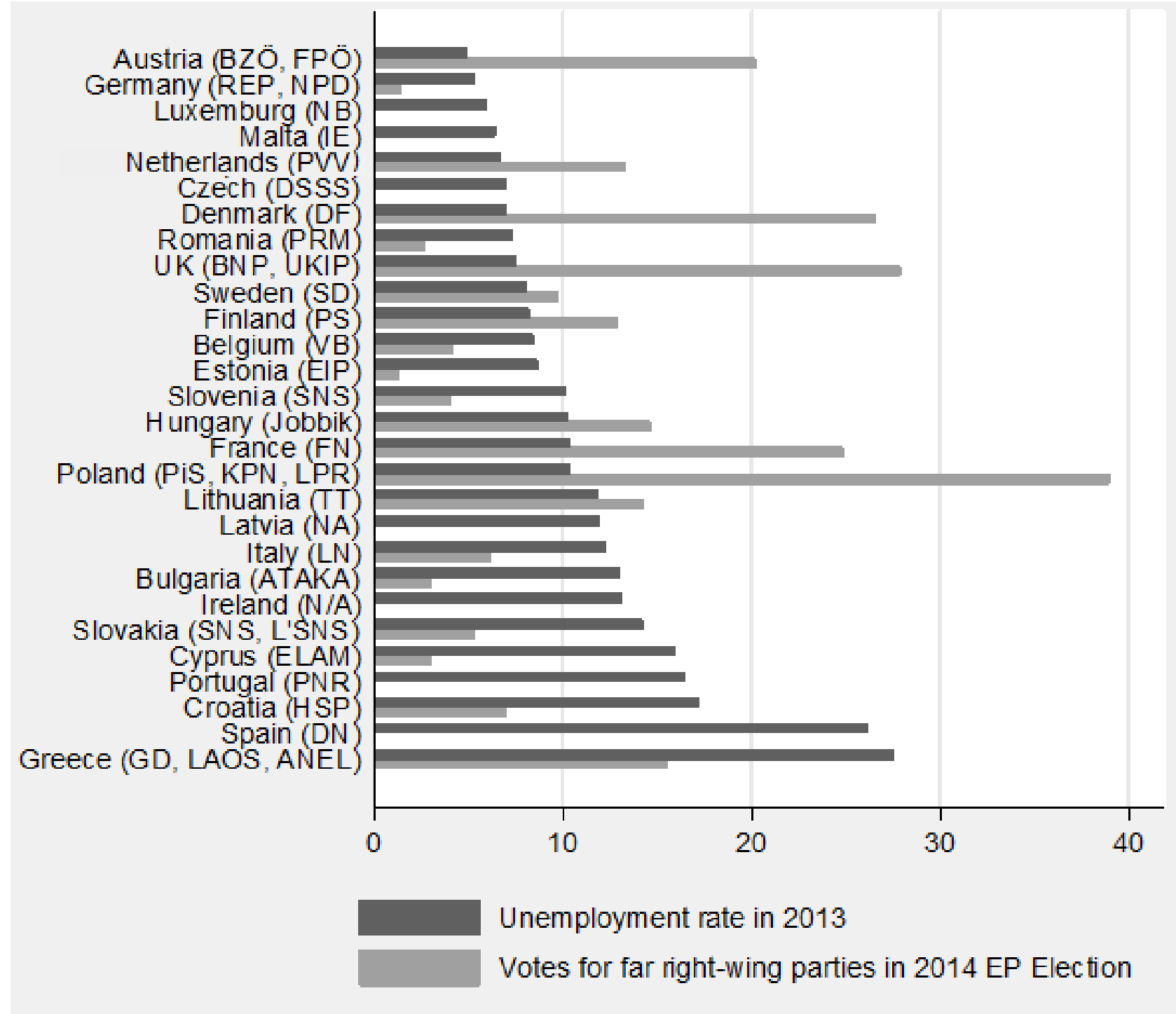




\section{Classifying and explaining the success of far right parties}

\section{Classification}

The 'extreme' (Ignazi 1991), 'radical' (Rydgren 2007), 'populist-radical' (Mudde 2007; Immerzeel et al 2015) or 'far' (Lucassen and Lubbers 2012; Vasilopoulou and Halikiopoulou 2015) right party family has been characterised as one of the least homogenous party families (Ennser 2012). Part of the problem in generating a broad theory of patterns of far right party support is precisely this question of classification: which parties should we compare? Do these parties belong to the same party family, and are therefore comparable groups, or are the variations between them so fundamental that a comparison is not possible? Sharp distinctions may be identified in terms of the social groups these parties attract, the extent to which their voters have right authoritarian attitudes, the relationship of the parties themselves with democracy, their association with fascism, the harshness of their stance towards the European Union (EU) and the extent to which they employ violence to materialise their goals.

Any attempt at classification faces methodological as well as theoretical problems. Classifying these parties in terms of who votes for them can result in circular reasoning. If these parties have a different voting base because they are different types of parties, then the causal logic is skewed. Classifying these parties in terms of their ideology poses a problem for theorising insofar as ideology may not create clearly defined categories. Another problem refers to the governmentopposition dynamics: as a party moves closer to power it may moderate its position shifting between categories; or a party may radicalise in order to compete with other parties in the system. Nonetheless and despite these problems, a classification remains useful as it creates a 
starting point for any comparative study that seeks to understand the varied success of these parties.

The key is that, while diverse, these parties also share a number of core common features that permit them to be grouped together. First and foremost, this refers to a harsh stance on immigration driven by nationalism (Eatwell 2000; Hainsworth 2008; Halikiopoulou et al. 2012). This has been conceptualised by Mudde (2010) as nativism, a concept that describes the ethnic variant of nationalism, i.e. the definition of the nation in accordance to ascriptive criteria, leading to calls for the maintenance of the homogeneity of the nation (Halikiopoulou et al. 2012). These parties also share authoritarianism and populism (Mudde 2007).

This paper favours the overarching term 'far right', and within it a distinction between 'extreme' and 'radical' variants which captures both the commonalities and variations within this party family. The term 'far' allows inclusion of all parties that share a nationalist anti-immigrant agenda, authoritarianism and populism. The distinction between 'extreme' and 'radical' captures the parties' relationship with procedural and substantive democracy (Mudde 2010) as well as a past association with fascist groups and the use of violence. This paper therefore adopts the term 'far right' to describe parties that (a) belong to the same party family; (b) are characterised by nationalism, authoritarianism and populism and (c) differ in terms of their relationship with democracy, the extent to which they have a fascist past and the extent to which violence forms part of their agenda. This means including some of the borderline cases, but in a way that clearly captures their specificities. In line with Immerzeel et al 2015 we include extreme right variants such as BNP, PNR, and Jobbik as well as more radical variants such as DF, PVV and UKIP. We add 
the GD, Independent Greeks (ANEL) (Vasilopoulou and Halikiopoulou 2015) and the Cypriot National Popular Front (ELAM) (Katsourides 2013), as well as the Polish populist radical Law and Justice Party (PiS) which has moved progressively to the nationalist right of the political spectrum since mid 2000s (Pankowski 2010:152; Harrison and Bruter 2011; Pankowski and Kormak 2013). Overall we examine 36 parties in $28 \mathrm{EU}$ member states (see Appendix 2).

State of the art: what explains demand for far right parties?

How may we conceptualise support for the far right? In the vast majority of accounts, support for the far right is theorised on the basis of a demand and supply framework examined at the micro level. The former refers to bottom up theories capturing any factors that increase the 'demand' for far right parties, while the latter refers to top down institutional factors. The demand framework is governed by an overarching rationale that rests on the premise that societal conditions determine party success. Most demand-side explanations emphasise the importance of economic factors. The key is some type of exogenous trigger factor, for example economic crisis, globalization, internationalization, that impacts negatively on either the socio-economic status of voters, or their expectations. Economic interests may underline far right party support through several causal mechanisms, which are either objective or subjective; about levels or change; and current or future/expected. While some emphasise the level of the problem, others focus on the perceptions of the problem or on the change in the problem. The 'modernization losers' thesis contends that those more likely to support far right parties are the losers of socio-economic change (Kriesi 1999). It is consistent with the notion that globalization leads to the formation of a new structural conflict in Western European countries (Kriesi et al 2006). The socio-demographic model focuses on the 
objective current socio-economic conditions of voters (Lipset 1960; Betz 1994; Rydgren 2007). The relative deprivation thesis merges economics with subjective characteristics of voters focusing on the extent to which a deteriorating economic condition will worsen an individual's position, understood in comparison either with one's own past or with another social group (see, e.g. Lubbers and Scheeppers 2002;). Realistic conflict theory posits that people are in competition over scarce resources, understanding the rise of the far right in terms of a struggle for access to the collective goods of the state (Wimmer 1997; Lucassen and Lubbers 2012).

These theories expect certain types of social groups who are either experiencing deprivation in their present situation or who expect deprivation in the future to be the likely supporters for the far right. Within this context, both high levels of unemployment and/or sharp increases in the levels of unemployment are expected to be associated with far right party support (Lubbers and Scheepers 2002). Those who are unemployed, lowly-educated, involved in manual employment and, more generally, have low incomes are expected to be the key electoral constituency of far right parties. Studies rarely distinguish between the likelihood of opting for the far right vis-à-vis the far left among certain groups such as the unemployed. But overall, theories that focus on the economy tend to associate unemployment with far right party support because of protest and anti-systemic attitudes, linkage with unfavourable out-group attitudes and authoritarian attitudes (Lubbers and Scheepers 2002:134). Another reason is competition with immigrants and outsiders for jobs, welfare, and more broadly access to the collective goods of the state (Wimmer 1997).

Recent studies, however, have found that cultural factors matter more for far right party support than economic factors (Sniderman and Hangerboorn 2007; Ivarsflaten 2008; Lucassen and Lubbers 
2012); and that when economic factors do matter they do so in different ways across cases (Lubbers and Scheepers 2002; Vasilopoulou and Halikiopoulou 2015). These different conclusions drawn in various studies, both within and across cases, have prompted scholars to note that demand-side economic factors in themselves may be poor predictors of far right party support (Mudde 2010; Lucassen and Lubbers 2012).

The EP election results provide a good platform for testing the impact of the economy on far right party support at the national level across Europe. EP elections are 'second-order national contests' (Hix and Marsh 2007) that favour smaller parties. It could therefore be possible that the relationship between far right party support and the economy, as identified in literature focusing on national elections and micro-level analyses, is different in EP elections. Does the second-order effect, which entails that EP elections are more likely platforms for the expression of discontent with the national government, affect our theories about the relationship between unemployment and far right party support? In addition, given that most studies tend to assume that the political reactions to economic and cultural globalization are bound to manifest themselves above all at the national level (Kriesi et al 2006: 921-922), the examination of EP electoral results is a contribution to existing literature. But it is also a methodologically sound choice because EP elections allow us to sidestep endogeneity, timing and comparability issues. In contrast to national elections where the economy and far right party support are endogenous, EP elections results are unlikely to affect the economy. They offer a 'snapshot' of 28 different elections with standardized results at a particular point in time using a similar electoral rule. EP elections also provide a good reference point for understanding the rise of both radical right variants, which have been the most popular types of far right parties since the 1990s; and also the most extreme variants such as Jobbik and 
the Golden Dawn. These extreme variants have experienced a dramatic increase since 2010 contrary to most theories that have postulated that 'old' far right parties (Golder 2003) with clear links to fascism are unlikely to experience much support in post war Europe. Finally, EP elections provide a platform on which to test a model of far right party support across Western and Eastern Europe, which are rarely examined together.

Risks, Costs and labour markets: Theorising the impact of the economy on far right party support

This section develops our expectations concerning the effect of unemployment in two steps. In the first step, we build on the demand side literature reviewed in the previous section to conceptualise the effect of unemployment on far right party support through a framework that emphasises societal risks and costs. In a second step, we build on welfare state literature to stress the role of labour market institutions in moderating these risks and costs.

Economic factors affect demand through risks and costs

As discussed in the previous section, unemployment is shown to be related to far right party support in most of the demand side literature. Theorising how economic factors may lead to support requires reconceptualising how unemployment may affect insecurity (Kitschelt with McGann 1995; Swank and Betz 2003; Anderson and Pontusson 2007). Economic problems may affect demand for the far right through two empirically related - but conceptually distinct channels. We term these two channels 'risk' and 'cost': economic factors may mean higher far right support because of higher cost or higher risk, or both. In the case of labour market problems, 
the first - cost - channel is that unemployment may increase support because more people are unemployed and the unemployed are more likely to vote for extreme right parties (Lubbers and Scheepers 2002; Rydgren 2007) for the various reasons explained above, including protest voting, authoritarian attitudes, negative attitudes towards out-groups and competition for state goods with outsiders (Wimmer 1997).

That unemployment imposes a cost on someone is not contested, whether in terms of well-being, life satisfaction, or other metrics (e.g. Jahoda 1988; Gerlach and Stephan 1996). There is also widespread evidence in the labour market literature that unemployed and atypical workers have different policy preferences from those in employment because they face much higher risks (Rueda 2005; Rueda 2007; Emmenegger 2012; Vlandas 2013; Marx and Picot 2013; Marx 2014). Labour markets have become increasingly dualized with insiders in permanent contracts and those in non-standard jobs and unemployment have seen their risks, entitlements, and policy preferences diverge (Emmenegger et al 2012).

But labour market problems may also have an effect through a second - risk - channel, via the effects of higher unemployment on the perceived risk of unemployment of those currently in jobs. Indeed, as unemployment increases, this also affects the well-being of those currently in jobs (Hartley et al. 1991; De Witte 1999; Clark 2003; Böckerman 2004). This is because when general market conditions deteriorate, this also affects the perception of insecurity of employed workers (Chung and Carr 2014; Chung and Van Oorschot 2011; Mau, Mewes and Schöneck, 2012). In addition, workers that were previously unemployed continue to feel more insecure even after returning to work (Böckerman 2004; Erlinghagen 2008). 
Thus, unemployment may affect electoral choice through its effect on economic insecurity (cf. Mughan and Lacy 2002). Higher unemployment should ceteris paribus increase national support for far right parties among both unemployed and employed. As a result, we expect unemployment to be significantly associated with higher far right support:

Hypothesis 1: Unemployment is positively associated with far right party support

\section{Costs can be compensated}

Losing one's employment has a direct income effect through the loss of wages. However, in most European countries unemployed workers are entitled to some replacement of their previous income in the form of unemployment benefits (Van Vliet and Caminada 2012). The cost of being unemployed therefore depends on the generosity of unemployment benefits: in countries with generous benefits, the cost of unemployment relative to employment is lower. As a result, the extent to which we should expect higher unemployment to lead to more far right support is crucially contingent on labour market institutions. Consistent with this, various studies find that workers report lower levels of job insecurity in European countries where unemployment benefits are more generous (OECD 2004; Clark and Postel Vinay 2005; Mau, Mewes and Schöneck 2012).

Labour market policies can also compensate costs by minimising its duration. Using the European Social Survey, Chung and Van Oorschot (2011) confirm that generous unemployment benefits provide a sense of security by partly replacing lost income. Labour market policies can also mediate the effect of unemployment on other potentially relevant facets of welfare. Chung and 
Carr (2014) analyse employment insecurity and life satisfaction in 22 countries and highlight that labour market policies may mitigate the adverse effects of unemployment on life satisfaction. In sum, there is significant evidence that unemployment affects individuals' welfare at the micro level and that institutions mediate this impact.

Moreover, globalisation 'increases social dislocations and economic insecurity, as the distribution of incomes and jobs across firms and industries becomes increasingly unstable' (Garrett 1998: 7). However, our theoretical framework would suggest that globalisation does not by itself lead to far right support but is instead mediated by welfare state institutions. This is precisely what Swank and Betz (2003) find: countries with generous systems of social protection are less likely to exhibit significant 'radical right populist parties'- i.e. the new far right parties that have experienced increasing support since the 1990's on platforms that emphasise an ideological and organizational disassociation from fascism. This is because - as we discuss above - generous welfare state policies may compensate and mitigate economic insecurities brought about by globalization.

Do these dynamics apply at the national level? While our conceptual framework is consistent with Swank and Betz's (2003) findings, we test this logic on a different and broader phenomenon to identify cross-national patterns in EP elections. In addition, while Swank and Betz (2003) focus on parties that 'typically embrace neoliberal economic programmes, xenophobia and strident antiestablishment positions' (2003: 218), we want to test this framework on all far right parties. Our sample includes extreme right variants such as GD that have experienced a significant rise since the onset of economic crisis and have centred their rhetoric on welfare provision reminiscent of the Nazi winterhilfswerk (Vasilopoulou and Halikiopoulou 2015). While they focus on globalisation 
and the welfare state, we focus on unemployment and labour market institutions. We expect unemployment benefits to lower the cost of unemployment to the unemployed and therefore to reduce the cost of unemployment. If this is true, unemployment benefits should have both an independent effect and a mediating effect on national level far right party support:

Hypothesis 2: More generous unemployment benefits lower far right support

Hypothesis 3: More generous unemployment benefits mitigate the impact of unemployment on far right support

Risks can be mitigated

Costs are only one of the two key mechanisms through which unemployment could affect far right party support. The unemployed are only one casualty of rising unemployment. Those in employment may also be adversely affected by rising unemployment because they consider the risk that they will incur those costs and a higher risk negatively affects them. While this risk is influenced by unemployment, it is also determined by Employment Protection Legislation (EPL): where EPL is high, dismissal costs are also high, and an employer is ceteris paribus less likely to dismiss a particular employee in response to a downturn because the cost benefit calculation shifts in favour of keeping the employee. As a result, objective and perceived risks in society are crucially determined by the level of EPL. For instance, workers in permanent contracts that are protected by EPL and those in temporary contracts that are not, exhibit different degrees of insecurities and different policy preferences (Clark and Postel Vinay 2005; Rueda 2007; Vlandas 2013). Where it is 
easy to dismiss them, permanent workers will respond much more fearfully to a given rise in unemployment (for more on the effect of EPL on permanent workers, see Rueda 2005 and 2007; Emmenegger et al 2012; Vlandas 2013). The crisis is a good example of this dynamic. Governments' social policy efforts in response to higher unemployment during the crisis were lower in countries where workers in permanent contracts were highly protected from redundancy, because these workers were less concerned about losing their job and therefore did not push their governments to expand social policy initiatives (Rueda 2014).

In sum, welfare is likely to have a protective effect (cf Arzheimer 2009; Swank and Betz, 2003). Where EPL is high, permanent workers have less to fear from unemployment since they are unlikely to be made redundant. An increase in unemployment should only lead to higher far right party support in countries with low EPL. By contrast, our expectations concerning the relationship between the level of EPL itself and far right party support is more indeterminate. As the labour economics literature suggests, EPL not only reduces flows into unemployment but also reduce the probability of finding a job for the unemployed (OECD 1994; Bassanini and Duval 2006, 2009). This would mean that the two effects may cancel each other out, and indeed there is mixed evidence concerning the impact of EPL on unemployment (Baccaro and Rei 2007). Consequently, a higher EPL may make the employed more secure while making the unemployed more insecure. The average effect of EPL is therefore uncertain: if the effect on workers dominates, unemployment should have a negative effect on far right support; if the effect on the unemployed dominates, the reverse should be true; and if both effects are equivalent, the association should be insignificant. We derive two hypotheses from this discussion: 
Hypothesis 4: more stringent job security regulation is not significantly associated with far right party support

Hypothesis 5: more stringent job security regulation lowers the impact of unemployment on far right party support

\section{Data, estimation strategy and results}

\section{Data}

We collect data on several variables that allow us to test these hypotheses while controlling for other demand and supply factors that have been identified in previous literature discussed earlier. Note that all independent variables are - where data is available - in the year before the election takes place (e.g. 2013 unemployment rate for May 2014 election). In some cases, data is not available for 2013, and we therefore have to rely on 2012 data or in very few cases on 2011 data, but this is never the case for fast moving economic variables. Descriptive statistics, definitions and sources of all variables are discussed in Table A1 in the appendix.

To test the economic impact of the labour market, we rely on the overall unemployment rate (as \% of total) both because it captures the biggest problem in the labour market but also because it receives the most attention from the public. Since people vote on the basis of their situation prior to the election, we use data on the unemployment rate for the year prior to the EP election (e.g. 2013 for the 2014 election). We also test the effect of alternative measures of labour market problems (e.g. youth unemployment rate and long term unemployment rate). 
Next, we want to measure the risk and cost of unemployment. To capture risk, in addition to the national unemployment rate, we rely on the index of EPL for regular workers developed by the OECD. The higher the EPL index, the less likely workers in permanent contracts will fear losing their job in the face of increasing unemployment. To capture cost, we rely on the unemployment benefit replacement rate, which captures the size of the income loss upon becoming unemployed. We expect EPL and unemployment benefits to mediate the effect of unemployment on the far right, and unemployment benefits to lower far right party support but have no expectations concerning the independent effect of EPL (i.e. when it is not interacted).

We include a number of controls for demand side factors. The first set of controls we include is real GDP growth. We also test for the effect of budgetary stress (debt and deficit as a \% of GDP). A second control concerns the impact of deindustrialisation, which has received some attention in the far right literature (e.g. Kitschelt 2007). The third set of controls concerns the role of internationalisation, which previous literature has focused on. Kriesi (2014) argues that the populist right is more likely to mobilise in defence of the national identity and the nation-state that internationalisation may be undermining. Lucassen and Lubbers (2012) argue that perceived cultural ethnic threats appear a stronger predictor of far-right preferences than perceived economic ethnic threats. Thus, any international forces that threaten the state (e.g. globalisation) or national identity (e.g. immigration) could be expected to lead to greater far right support. We include three measures to test these expectations. First, we include total trade (sum of exports and imports) as a share of GDP. Second, we investigate whether immigration affects far right support. Third, as a robustness check we construct a variable that captures anti-immigrant feeling. The European Social Survey asks respondents to position themselves on the following statement: 
"Country's cultural life undermined or enriched by immigrants". They choose a number between 0 (Cultural life undermined) and 10 (Cultural life enriched). Our variable sums the share of respondents that have responded 0 to 4 (since 5 is a neutral position, it is not included in our "immigration is bad for culture" variable).

To account for supply- side dynamics, we consider the role of several factors. First, to capture the extent to which national electoral systems give space to far right votes in national elections, we rely on whether there is a proportional electoral system in the country. We expect proportional systems to exhibit lower far right support in EP elections because dissatisfied voters can voice their discontents in national elections. Second, we consider the extent to which the party system is open. Our baseline indicator is an index of electoral fractionalisation ${ }^{2}$ but we also test the effect of the effective number of political parties ${ }^{3}$ in each country.

Finally, we test two contextual factors. The first contextual factor is whether countries have a postcommunist past because there are variations between Eastern and Western Europe (Mudde 2007; Halikiopoulou et al 2012). The second contextual factor is whether the last election was significantly different from the other two, even when controlling for all relevant economic factors (for instance because of a qualitatively different effect of the crisis). Both are captured by including a dummy variable coded 1 where the condition is present, and 0 otherwise.

\footnotetext{
${ }^{2}$ Index of legislative fractionalization of the party system according to the formula [F] proposed by Rae (1968).

${ }^{3}$ Effective number of parties on the votes level according to the formula [ $\left.\mathrm{N}_{2}\right]$ pro-posed by Laakso and Taagepera (1979). The effective number of parties uses the same information as the Rae-Index and is calculated from this index as follows: effpar_ele $=1$ / ( 1 - rae_ele $)$
} 
Because we are interested in explaining variation across countries, the inclusion of country fixed effects would 'explain away' what we are trying to explain. Indeed, as Plümper, Troeger and Manow (2005: 331) argue, "unit dummies completely absorb differences in the level of independent variables across units". Thus, the 'level effect' of our key independent variables (e.g. unemployment benefits) is suppressed when including fixed country effects (ibid: 333 ). While the effect of a change in unemployment and unemployment benefits is also theoretically relevant, our main concern here is about the effect of the level of these variables on far right support. That being said, we do run one model with fixed effects and our results are unchanged. We are similarly reluctant to neutralise time effects that affect all countries homogenously and thus favour not including time effects (though we do run one model with time effects and the results are similar).

\section{Test and results}

We run a series of panel data regression analysis on $28 \mathrm{EU}$ countries in the last three EP elections. Given missing data, this results in 74 country-election year data points for most regressions and we always mention the number of observations for each regression result. We focus on the last three elections because European far right parties have changed over longer periods of time and because our primary interest is to compare, pre-crisis, early crisis and end of crisis times (i.e. 2004, 2009 and 2014). Our regressions include robust errors clustered by country to neutralise the effect of autocorrelation and heteroskedasticity.

Table 1 shows the results for our baseline model. Note that all independent variables are standardised around mean 0 with standard deviation of 1 which means the coefficients are directly comparable: they show the effect on far right support of a 1 standard deviation change in the 
independent variable. The unemployment rate has no statistically significant effect in all columns so we find no evidence for hypothesis 1 . Real GDP growth and total trade are similarly statistically insignificant. Other regressions (not shown, see table A2 in appendix) suggest that long term unemployment, youth unemployment, debt and deficit, exports and imports do not exhibit a statistically significant association with far right party support.

The coefficients for immigration and industrialisation are both statistically significant but only at the $10 \%$ level. We test alternative measures and find that both immigration from non-EU and from EU countries is indeed positively associated with higher far right support (Table A2 in the appendix, columns 2 and 3). However, these results are not stable when including additional controls during our robustness checks (see columns 12 to 14 in table $A 2$ in the appendix): Spending on active labour market policies, OECD unemployment benefit replacement rate, Inequality ratio between top and bottom quintile, Gini coefficient.

Unemployment benefits has a strongly negative and statistically significant association with far right support (consistent with hypothesis 2): 1 standard deviation change in the replacement rate of unemployment benefit (about 14 percentage points change) is associated with between 6.8 and 3.6 points increase in voting share of the far right, depending on the specifications. For reference, 2 standard deviations amounts to the difference between the UK and Germany in 2011. Because our unemployment benefits data stops in 2011, we also carry out the same test with an OECD index of unemployment benefit replacement rate which stops in 2012, but has less country coverage (table A2 in appendix). The results are the same. Passive or active labour market 
spending itself does not matter, suggesting it is entitlements not spending that matters. EPL has no statistically significant effect (consistent with hypothesis 4).

We find that electoral fractionalisation and a proportional electoral system are negatively associated with far right party support but the number of parties does not seem to matter (column 6). While the effect of the PR system is mostly robust to alternative specifications this is not the case for electoral fractionalisation (see table $A 2$ in appendix). The dummy variable for postcommunist countries is only statistically significant at the $10 \%$ level.

We also test the effect of additional factors in table A2 in the appendix. Inequality between the top and bottom $20 \%$ of the income distribution and the Gini coefficient have no statistically significant association with far right party support. The immigrant population and the crisis (dummy variable equal to 1 for 2014 election and 0 otherwise) have no effect. The share of the population that believe immigration is bad for the country's culture has no statistically significant effect (see column 15 in table A2). Finally, using the standard Eurobarometer number 80 (autumn 2013), we can calculate the bivariate correlation between far right party support and the percentage of respondents in each country that 'feel like a citizen of the EU' to check whether euroscepticism is a likely omitted variable of our analysis. The correlation coefficient is low (-0.14) and clearly statistically insignificant (0.46). 
Table 1: Baseline results for the determinants of far right support

\begin{tabular}{|c|c|c|c|c|c|c|c|c|c|c|}
\hline Column & $(1)$ & $(2)$ & (3) & (4) & $(5)$ & (6) & (7) & $(8)$ & (9) & (10) \\
\hline \multirow[t]{2}{*}{ Unemployment rate } & 0.37 & 0.19 & 0.67 & 0.52 & 0.27 & 0.38 & 0.29 & -0.15 & -0.42 & -0.63 \\
\hline & $(0.628)$ & $(0.831)$ & $(1.097)$ & $(0.586)$ & $(0.662)$ & $(0.662)$ & $(0.671)$ & $(0.751)$ & (0.689) & $(0.857)$ \\
\hline \multirow[t]{2}{*}{ Real GDP } & -0.45 & 0.46 & 0.25 & -0.15 & -0.63 & -0.68 & -0.61 & -0.39 & 0.30 & -1.22 \\
\hline & $(0.554)$ & $(0.485)$ & $(0.735)$ & $(0.668)$ & $(0.769)$ & $(0.800)$ & $(0.770)$ & $(0.747)$ & $(0.645)$ & $(1.162)$ \\
\hline \multirow[t]{2}{*}{ Unemployment benefits } & $-4.19 * *$ & $-3.62^{*}$ & $-4.13^{*}$ & $-5.41 * * *$ & $-4.32 * *$ & $-3.88^{*}$ & $-4.33 * *$ & $-4.66^{* *}$ & $-5.25 * *$ & $-6.80 * * *$ \\
\hline & $(1.564)$ & (1.539) & (2.034) & $(1.635)$ & $(1.595)$ & $(1.618)$ & $(1.596)$ & $(1.608)$ & $(1.602)$ & $(1.982)$ \\
\hline \multirow[t]{2}{*}{ Electoral fractionalisation } & $2.46^{*}$ & $2.32 *$ & $4.73^{*}$ & $2.99 * *$ & $2.62 * *$ & & $2.65^{* *}$ & $2.59 * *$ & $2.74^{* *}$ & $2.27^{\mathrm{t}}$ \\
\hline & (0.999) & (0.932) & $(2.012)$ & $(1.090)$ & (0.909) & & $(0.923)$ & $(0.864)$ & $(0.896)$ & $(1.307)$ \\
\hline \multirow[t]{2}{*}{ Immigration } & & & $4.83^{t}$ & & & & & & 1.84 & $2.08^{t}$ \\
\hline & & & (2.819) & & & & & & $(1.128)$ & $(1.160)$ \\
\hline \multirow[t]{2}{*}{ Post-communist dummy } & & & & $-6.15^{\mathrm{t}}$ & & & & & & \\
\hline & & & & (3.280) & & & & & & \\
\hline \multirow[t]{2}{*}{ Proportional Representation } & & & & & $-11.63 * * *$ & $-11.89 * * *$ & $-11.75^{* * *}$ & $-9.36 * * *$ & $-7.01 *$ & $-7.42 *$ \\
\hline & & & & & $(2.025)$ & $(2.147)$ & $(2.155)$ & $(2.515)$ & (3.392) & (3.769) \\
\hline \multirow[t]{2}{*}{ Effective number of parties } & & & & & & 1.60 & & & & \\
\hline & & & & & & $(0.988)$ & & & & \\
\hline \multirow[t]{2}{*}{ Total trade (\% GDP) } & & & & & & & 0.11 & -0.62 & -0.50 & 0.67 \\
\hline & & & & & & & $(0.735)$ & $(0.876)$ & $(0.977)$ & $(1.558)$ \\
\hline \multirow[t]{2}{*}{ Share of industry } & & & & & & & & $-1.83^{t}$ & $-2.41 *$ & $-2.63 *$ \\
\hline & & & & & & & & $(1.047)$ & $(1.054)$ & (1.309) \\
\hline \multirow[t]{2}{*}{ EPL } & & & & & & & & & & 0.80 \\
\hline & & & & & & & & & & $(1.288)$ \\
\hline Constant & $7.47 * * *$ & $5.23 * * *$ & $18.79 * * *$ & $9.50 * * *$ & $18.61^{* * *}$ & $18.79 * * *$ & $18.72 * * *$ & $16.46 * * *$ & $14.45^{* * *}$ & $14.98 * * *$ \\
\hline Year effects & No & Yes & No & No & No & No & No & No & No & No \\
\hline Country effects & No & No & Yes & No & No & No & No & No & No & No \\
\hline Observations & 76 & 76 & 72 & 76 & 73 & 73 & 73 & 73 & 69 & 56 \\
\hline Number of countries & 27 & 27 & 27 & 27 & 26 & 26 & 26 & 26 & 26 & 21 \\
\hline R-squared within model & 0.17 & 0.29 & 0.25 & 0.17 & 0.17 & 0.12 & 0.17 & 0.16 & 0.23 & 0.31 \\
\hline R-squared overall model & 0.19 & 0.19 & 0.85 & 0.25 & 0.35 & 0.32 & 0.35 & 0.40 & 0.41 & 0.44 \\
\hline R-squared between model & 0.21 & 0.19 & 1.00 & 0.29 & 0.42 & 0.39 & 0.42 & 0.48 & 0.49 & 0.45 \\
\hline
\end{tabular}


Hypotheses 3 and 5 are about interactions between labour market institutions and unemployment. This requires running a regression while including an interaction term between unemployment and unemployment benefits, as well as between unemployment and EPL. The interaction effects' magnitude and significance cannot be evaluated from the table results (see Brambor et al. 2006). We therefore run two separate models and plot the average marginal effects of unemployment conditional on unemployment benefits and EPL, respectively. The top left panel of Figure 2 shows that unemployment does have a positive association with far right party support in countries where unemployment benefits replace strictly less than $50 \%$ of previous income while working; beyond this level unemployment is no longer significantly different from 0 . The top right panel of Figure 2 shows that unemployment does have a positive association with far right support in countries where the OECD EPL index is lower than slightly above 2; beyond this level unemployment is no longer significantly different from $0 .{ }^{4}$ Since we use the $10 \%$ significance level as our maximum threshold for statistical significance, both panels plot $90 \%$ confidence interval. In the bottom two panels, we show the results for more demanding (95\%) confidence intervals: the results are substantively the same but the impact of unemployment is only positive for slightly lower values of EPL than before.

\footnotetext{
${ }^{4}$ The full regression results are shown in Table $A 3$ in the appendix and suggest that immigration and electoral fractionalisation continues to be statistically significant and positive.
} 
Figure 2: Effect of unemployment rate on far right support conditional on unemployment benefit generosity and EPL

Average $M$ arginal $E$ ffe cts of unemployment rate with $90 \% \mathrm{Cls}$

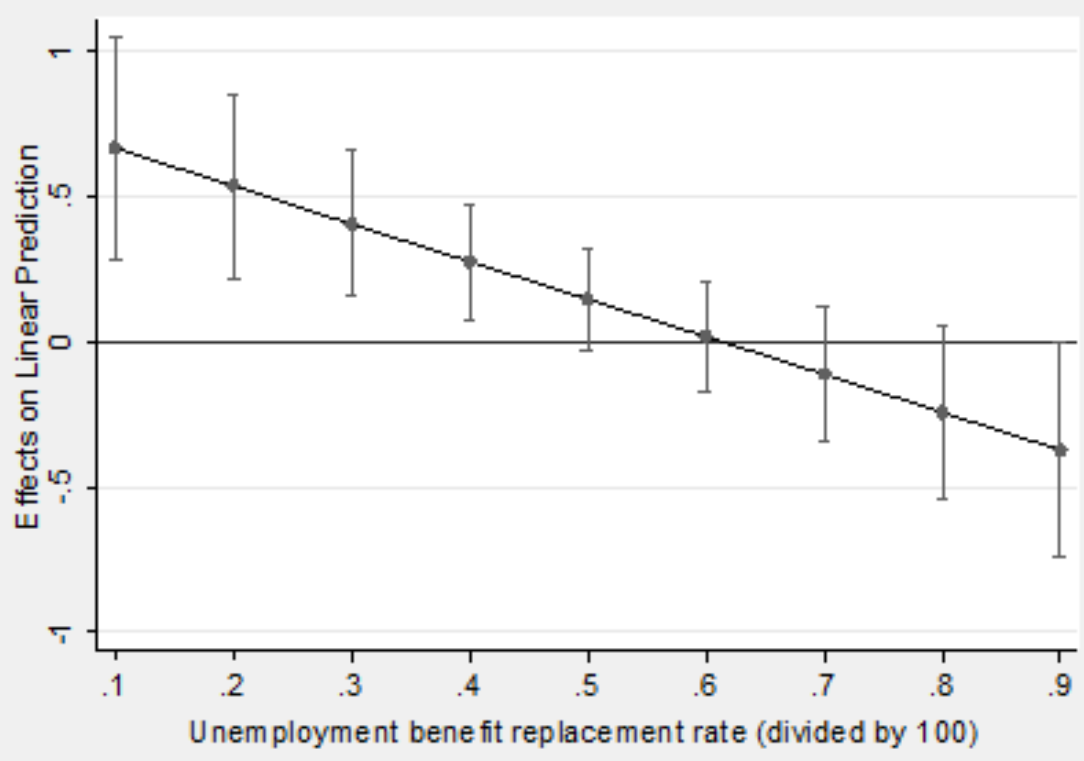

With $95 \%$ confidence intervals

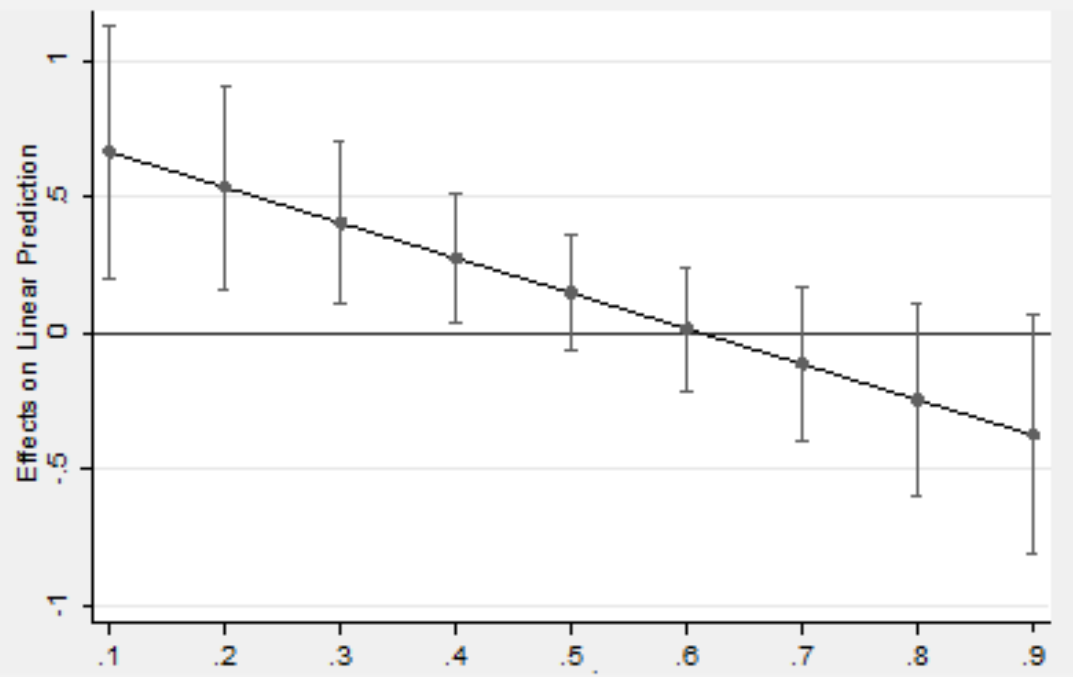

Average Marginal Effects of unemployment rate with $90 \%$ Cls
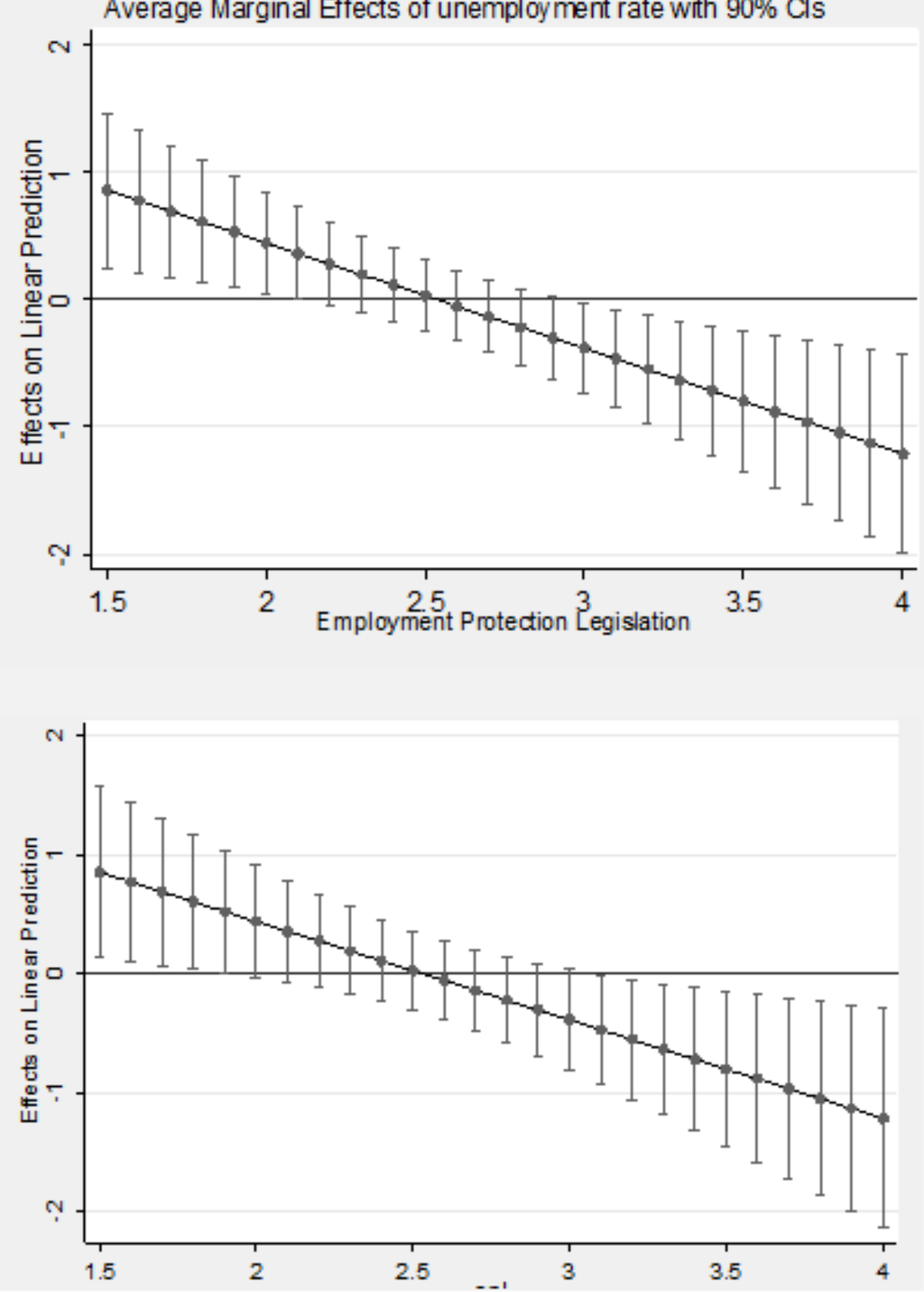
In other words and consistent with hypotheses 3 and 5, unemployment does not increase costs and risks sufficiently in countries with high EPL and high unemployment benefits. This finding captures what has happened in Spain, Portugal and Italy where unemployment has increased, but the replacement is higher than $60 \%$ and EPL higher than 2, so that the far right has either remained stable and low (Spain and Portugal), or has fallen (Italy). By contrast, Greece, the UK ${ }^{5}$, Hungary and Poland all have unemployment benefit replacement rates that are lower than 0.5 and have seen their far right party support increase. France is an interesting outlier, having high unemployment benefits but also a high score of far right. This could be because of other casespecific, micro-level or supply-side dynamics, having for example to do with the discourse of Marine Le Pen, the activity of the party at the local level and party system dynamics.

Our macro level findings are consistent with Arzheimer's (2009: 274) findings using Eurobarometer survey data in Western Europe and analysing both individual and contextual level effects. It is particularly important to compare our findings to this study not only because it is one of few cross-national study on the topic but more importantly because some of his analysis investigates macro-micro interactions. Using a different proxy, Arzheimer (2009: 269) also finds that the amount of immigration in a country has a positive effect on the probability that an individual votes far right. ${ }^{6}$ Also similarly to our results, his results suggest a statistically significant effect of unemployment benefits in reducing far right party support, though he

\footnotetext{
${ }^{5}$ The UK has both a very low unemployment benefit replacement rate and a fairly high far right party support which may be driving the results. We therefore rerun the results without the UK as a robustness check: the results are the same (see table $\mathrm{A} 4$ and figures $\mathrm{A} 1$ and $\mathrm{A} 2$ in the appendix.

${ }^{6}$ Specifically he finds that "higher levels of immigration are associated with higher support for extreme right" (ibid: 272).
} 
suggests this effect is overall not particularly strong (ibid: 271). While he does not investigate the effect of employment protection legislation, some of his findings concerning the interaction between unemployment benefit systems and unemployment rate in shaping the probability that an individual votes for the far right are relevant to our analysis and worth quoting at length. Like us he finds that "a positive effect [of unemployment rates] becomes visible but only in contexts when either levels of immigration or benefits are very low" and that "at high levels of immigration, unemployment benefits reduce the impact of unemployment" (ibid: 272). This corroborates using micro level data that labour market institutions mediate the impact of unemployment on far right party support.

\section{Conclusion}

How may we understand the cross-national variation in the rise of far right parties in EP elections and what is the role of economic factors? While many theories focus on the effect of the economy, there are conflicting expectations concerning when this happens and contradictory findings. Previous literature has increasingly contended that the extent to which economic factors matter varies across cases; and that ethnic factors may play a greater role. But these have been primarily examined either in small $\mathrm{N}$ case studies, or at the micro level in national election contests. By contrast, there are few systematic studies that test the impact of the economy on the macro-level, attempting to address questions of cross-national variation. 
To address this issue this paper has reconceptualised micro-level analyses that focus on the effect of unemployment through a framework of costs, risks and the mediating role of labour market institutions. Building on previous work (Arzheimer 2009; Swank and Betz 2003), it developed several new hypotheses and tested them at the macro-level on the results of the last three EP elections in all EU member states. We found that unemployment, real GDP growth, debt and deficits have no statistically significant effect on far right party support at the national level. By contrast, our results confirm that labour market policies and institutions influence costs and risks: where unemployment benefits and dismissal regulations are high, unemployment has no effect, but where either one of them is low, unemployment leads to higher far right party support. Unemployment benefits - but not dismissal regulations - have a statistically significant negative relationship with far right support.

Our contribution is twofold. First, we test the impact of the economy on far right party support at the macro-level through a systematic comparison of far right parties across the EU 28 including both Western and Eastern European countries. Second, we show that far right party support is fuelled less strongly by national unemployment levels in countries with regulated labour markets and generous unemployment benefits.

Our finding that labour market institutions mediate the impact of the economy on far right party support in EP elections is not only interesting in itself, but also opens avenues for future research towards a more general theory of the economy's impact on far right party support. This paper has tested its hypotheses at the macro-level as an initial step. A most important second step would be an examination at the individual level, thus offering support for our 
hypotheses at both the macro and micro-levels. Which individuals are more likely to opt for far right parties and to what extent do labour market institutions influence their choices by impacting on the risks and costs of employment? Does EPL affect these choices? What happens when people become unemployed? Do fixed or flexible contracts impact far right party support? Applying this framework to national elections would yield valuable results with broad generalizability potential. We also posit a micro level mechanism linking insecurity, labour market institutions and voting preferences for far right parties that could be tested using survey data. Finally, this framework could also be tested on other party families, most notably the radical left given its emphasis on welfare and the labour market. While far left and far right parties converge of issues of 'welfare chauvinism' (De Koster et al 2012) and could be drawing voters from the same pool, they tend to be treated as separate in the literature. 


\section{References}

Arzheimer, K. (2009), Contextual Factors and the Extreme Right Vote in Western Europe, 19802002. American Journal of Political Science, 53, 259-275. doi: 10.1111/j.15405907.2009.00369.x

Baccaro, L. and Rei, D. (2007). 'Institutional Determinants of Unemployment in OECD Countries: Does the Deregulatory View Hold Water?', International Organization, 6: 527-569.

Bassanini, A. and Duval, R. (2006) 'Employment patterns in OECD countries: Reassessing the role of Policies and Institutions', in labour and social affairs Directorate for employment (ed.), Social, employment and migration working paper (Paris: OECD).

Bassanini, A. and Duval, R. (2009) 'Unemployment, institutions, and reform complementarities: re-assessing the aggregate evidence for OECD countries', Oxford Review of Economic Policy, 25/1: 40-59.

Betz H.-G. (1994) Radical Right-Wing Populism in Western Europe. New York: St. Martin's Press

Böckerman, P. (2004). 'Perception of job instability in Europe'. Social Indicators Research, 67(3): 283-314.

Brambor, T., Clark, W. R. and Golder, M. (2006) 'Understanding Interaction Models: Improving Empirical Analyses', Political Analysis 14: 63-82.

Chung, H. and Carr (2014) Employment insecurity and life satisfaction: The moderating 
influence of labour market policies across Europe Journal of European Social Policy October 1, 2014 24: 383-399

Chung, H. and Van Oorschot, W. (2011) Institutions versus market forces: Explaining the employment insecurity of European individuals during (the beginning of) the financial crisis Journal of European Social Policy October 1, 2011 21: 287-301

Clark, A. and Postel-Vinay, F. (2005) Job Security and Job Protection. CEP Discussion Paper No 678 February 2005 http://cep.Ise.ac.uk/pubs/download/dp0678.pdf

De Koster, W. P. Achterberg and J. van der Waal (2012) The new right and the welfare state: The electoral relevance of welfare chauvinism and welfare populism in the Netherlands, International Political Science Review, 34(1): 3-20.

De Witte, H. (1999): “Job Insecurity and Psychological Well-being: Review of the Literature and Exploration of Some Unresolved Issues", European Journal of Work and Organizational Psychology 8, 155-177.

Eatwell R. (2000) 'The rebirth of the extreme right in Western Europe?' Parliamentary Affairs, 53(3): 407-25.

Emmenegger P. (2012) Job Security Regulations in Western Democracies: a Fuzzy-Set Analysis. European Journal of Political Research 2012;50:336-364. 
Emmenegger P., Häusermann S., Palier B., Seeleib-Kaiser M. (2012) The Age of Dualization. Oxford: Oxford University Press.

Ennser, L. (2012) The homogeneity of West European party families: The radical right in comparative perspective, Party Politics 18: 151.

Esping-Andersen, G. (1990) The Three Worlds of Welfare Capitalism. Princeton University Press.

Falzon, M.A and Micallef, .M (2012) Rights, Roots and Routes: Local and transnational Contexts of Extreme Right Movements in Contemporary Malta in Mammone, A., Godin, E. and Jenkins, B. (Eds) (2012) Mapping the Extreme Right in Contemporary Europe: From Local to Transnational, Oxon: Routledge

Garrett, G. (1998). Partisan politics in the global economy. New York: Cambridge University Press.

Gerlach, K., and G. Stephan (1996): A paper on unhappiness and unemployment in Germany, Economics Letters 52, 325-330.

Golder, Matt. (2003) Explaining variation in the Success of extreme right parties in Western Europe. Comparative Political Studies, 36 (4): 432-466.

Hainsworth, P. (2008). The extreme right in Western Europe. Abingdon: Routledge.

Halikiopoulou, D., Nanou, K. and Vasilopoulou, S. (2012) 'The Paradox of Nationalism: The Common Denominator of Radical Right and Radical Left Euroscepticism', European Journal of 
Political Research, 51(4): 504-539.

Harrison, S. and Bruter, M. (2011), Mapping Extreme Right Ideology: An Empirical Geography of the European Extreme Right', Basingstoke: Palgrave Macmillan

Hartley, J., D. Jacobson, B. Klandermans, T. van Vuuren, with L. Greenhalgh and R. Sutton (1991): Job Insecurity: Coping with jobs at risk, London: Sage.

Hix, S. and Marsh, M. (2007) Punishment or Protest? Understanding European Parliament Elections. The Journal of Politics, Vol. 69:2, 495-510

Immerzeel, T., et al (2015) Competing with the radical right: Distances between the European radical right and other parties on typical radical right issues, Party Politics, DOI: $10.1177 / 1354068814567975$

Ivarsflaten, E. (2008). What unites right-wing populists in Western Europe? Re- examining grievance mobilization models in seven successful cases. Comparative Political Studies, 41: 323.

Jahoda, M. (1988): "Economic recession and mental health: Some conceptual issues", Journal of Social Issues $44,13-23$.

Kaufmann, E. (2014), 'It's the Demography, Stupid': Ethnic Change and Opposition to Immigration. The Political Quarterly, 85: 267-276. doi: 10.1111/1467-923X.12090 
Katsourides, Y. (2013) 'Determinants of Extreme Right Reappearance in Cyprus: The National Popular Front (ELAM), Golden Dawn's Sister Party', South European Society and Politics, 18:4

Kitschelt, H. with McGann, A. (1995) The Radical Right in Western Europe: A Comparative Analysis. Ann Arbor: University of Michigan Press.

Kitschelt, H. (2007) 'Growth and Persistence of the Radical Right in Postindustrial Democracies: Advances and Challenges in Comparative Research', West European Politics, 30(5): 1176-1206.

Kriesi, H. (2014) The Populist Challenge, West European Politics, 37(2): 361-378

Kriesi, H., Grande, E., Lachat, R., Dolezal, M., Bornschier, S., Frey, T. (2006) Globalisation and transformation of the national political space: Six European countries compared, European Journal of Political Research, 45(6): 921-956.

Lubbers, M., Gijsberts, M. and Scheepers, P. (2002), 'Extreme right-wing voting in Western Europe' European Journal of Political Research 41: 345-378

Lubbers, M. and Scheepers, P. (2002) French Front National Voting: a micro and macro perspective, Ethnic and Racial Studies, 25(1): 120-149.

Lucassen, G. and Lubbers, M. (2012). 'Who Fears What? Explaining Far-Right-Wing Preference in Europe by Distinguishing Perceived Cultural and Economic Ethnic Threats', Comparative Political Studies, 45(5): 547-574.

Mareš, M. (2012) Right-Wing Extremism in the Czech Republic, International Policy Analysis, 
Friedrich Ebert Stiftung

Marx, P. and Picot, G. (2013) The Party Preferences of Atypical Workers in Germany, Journal of European Social Policy, 23(2): 164-178.

Marx, P. (2014) 'Labour Market Risks and Political Preferences: The Case of Temporary Employment', European Journal of Political Research, 53(1): 136-159.

Mau, Steffen, Mewes, Jan and Schöneck, Nadine (2012) What determines subjective socioeconomic insecurity? Context and class in comparative perspective Socio-Economic Review October 1, 2012 10: 655-682

Mudde, C. (2007) Populist radical right parties in Europe. Cambridge; New York: Cambridge University Press.

Mudde, C. (2010) 'The Populist Radical Right: A Pathological Normalcy', West European Politics, 33(6): 1167-1186.

Minkenberg, M. and Perrineau, P (2004) The Radical Right in the European Elections 2004, International Political Science Review, 28(1): 29-55

Mughan, A. and Lacy, D. (2002). Economic performance, job insecurity and electoral choice, British Journal of Political Science 32(4): 513-533.

OECD, 'Jobs Study', (Paris: OECD, 1994).

OECD. (2004). 'Employment Protection Regulation and Labour Market Performance' OECD 
Employment Outlook 2004 (pp. 61-125). Paris: OECD.

Pankowski, R., (2010) The Populist Radical Right in Poland: The Patriots, Oxon: Routledge

Pankowski, R and Kormak, M., (2013) 'Radical Nationalism in Poland: From Theory to Practice'

In R. Melzer and Serafin, S. (Eds.), Right-wing extremism in Europe: Counter-strategies and Labor-Market Oriented Exit Strategies. Friedrich Ebert Foundation.

Plümper, T., Troeger, V., Manow, P. (2005) Panel data analysis in comparative politics: Linking method to theory, European Journal of Political Research 44: 327-354.

Pytlas, B. (2013) 'Radical-right narratives in Slovakia and Hungary: historical legacies, mythic overlaying and contemporary politics', Patterns of Prejudice, 47(2): 162-183

Rueda D. (2005) Insider-Outsider Politics in Industrialized Democracies: The Challenge to Social Democratic Parties. American Political Science Review, 99:61-74.

Rueda D. (2006) Social Democracy and Active Labour Market Policies: Insiders, Outsiders, and the Politics of Employment Promotion. British Journal of Political Science, 36:385-406.

Rueda D. (2007) Social Democracy Inside Out. Oxford: Oxford University Press.

Rueda, D. (2014) Dualization, crisis and the welfare state. Socioeconomic Review, 12(2): 381407.

Rydgren, J. (2007) The Sociology of the Radical Right, The Annual Review of Sociology, 33:241262. 
Rydgren, J. (ed). (2013) Class Politics and the Radical Right, Oxon: Routledge

Reif, K. and Schmitt, H. (1980). Nine Second-Order National Elections: A Conceptual Framework for the Analysis of European Election Results. European Journal of Political Research 8 (1): 3-45.

Scheve Kenneth and Slaughte, Matthew J. (2004) Economic Insecurity and the Globalization of Production. American Journal of Political Science Volume 48, Issue 4, pages 662-674, October 2004.

Sniderman, P., and Hagendoorn, L. (2007). When ways of life collide. Princeton, NJ: Princeton University Press.

Swank, D and Betz, HG. (2003) Globalization, the Welfare State and Right-Wing Populism in Western Europe, Socio-Economic Review, 1: 215-245.

Van Vliet, O. and Caminada, K. (2012), 'Unemployment replacement rates dataset among 34 welfare states 1971-2009: An update, extension and modification of Scruggs' Welfare State Entitlements Data Set', NEUJOBS Special Report No. 2, Leiden University

Van der Eijk, C and Franklin, M (eds). (1996) Choosing Europe? The European Electorate and National Politics in the Face of Union. Ann Arbor: University of Michigan Press.

Vasilopoulou, S. (2011) 'European Integration and the Radical

Right: Three Patterns of Opposition', Government and Opposition 46 (2): 223-244 
Vasilopoulou, S. and Halikiopoulou, D. (2015) The Golden Dawn's Nationalist Solution: Explaining the Rise of the Far Right in Greece, New York: Palgrave. ISBN 9781137487124.

Vlandas, T. (2013) The politics of temporary work deregulation in Europe: solving the French puzzle. Politics and Society, 41 (3): 425-460.

Wimmer, A. (1997). Explaining xenophobia and racism: a critical review of current research approaches, Ethnic and Racial Studies, 20(1): 17-41. 


\section{Appendix}

Table A1: descriptive statistics, definitions and sources for variables

\begin{tabular}{|c|c|c|c|c|c|c|c|}
\hline Variable & Observations & Mean & Std. Dev. & Minimum & Maximum & Description & Sources \\
\hline $\begin{array}{l}\% \text { vote for far right } \\
\text { parties }\end{array}$ & 80 & 7.410 & 8.75778 & 0 & 38.93 & $\begin{array}{l}\% \text { vote for far right parties. For } \\
\text { our classification see Appendix } 2 . \\
\text { Years used for each country: } \\
2004,2009 \text { and } 2014 \text {. }\end{array}$ & $\begin{array}{l}\text { For far right results: EU } \\
\text { Election Database } \\
\text { http://eed.nsd.uib.no/webvi } \\
\text { ew/index.jsp?study=http://1 } \\
\text { 29.177.90.166:80/obj/fStud } \\
\text { y/ATEP2004_Display\&nod } \\
\text { e=0\&mode=cube\&v=2\&cu } \\
\text { be=http://129.177.90.166:8 } \\
\text { 0/obj/fCube/ATEP2004 Di } \\
\underline{\text { splay_C1\&top=yes }} \\
\text { and } \\
\text { http://www.europarl.europa } \\
\text {.eu/elections2014- } \\
\text { results/en/election-results- } \\
\text { 2014.html }\end{array}$ \\
\hline $\begin{array}{l}\text { Unemployment } \\
\text { rate }\end{array}$ & 84 & 8.736 & 4.525451 & 3.1 & 27.5 & $\begin{array}{l}\text { Unemployment rates represent } \\
\text { unemployed persons as a } \\
\text { percentage of the labour force. } \\
\text { Years used for each country: } \\
2003,2008 \text { and } 2013 \text {. }\end{array}$ & Eurostat \\
\hline Crisis dummy & 84 & 0.25 & 0.435613 & 0 & 1 & 1 for 2014,0 otherwise & Author's calculation \\
\hline Real GDP & 83 & 1.516 & 2.709865 & -5.4 & 8.6 & $\begin{array}{l}\text { Real GDP growth rate - volume. } \\
\text { Percentage change on previous } \\
\text { year. Years used for each } \\
\text { country: } 2003,2008 \text { and } 2013 .\end{array}$ & Eurostat \\
\hline $\begin{array}{l}\text { Post-communist } \\
\text { dummy }\end{array}$ & 84 & 0.357 & 0.482035 & 0 & 1 & $\begin{array}{l}\text { Equals } 1 \text { for } 12 \text { countries that } \\
\text { joined the EU in } 2004 \text { and } 2007 \\
\text { enlargements (excluding Cyprus }\end{array}$ & Author's calculation \\
\hline
\end{tabular}




\begin{tabular}{|c|c|c|c|c|c|c|c|}
\hline Variable & Observations & Mean & Std. Dev. & Minimum & Maximum & Description & Sources \\
\hline & & & & & & and Malta) & \\
\hline $\begin{array}{l}\text { Unemployment } \\
\text { benefits }\end{array}$ & 79 & 0.583 & 0.137381 & 0.26 & 0.9 & $\begin{array}{l}\text { Net unemployment replacement } \\
\text { rate for an average worker, one } \\
\text { earner couple with two children. } \\
\text { The dataset scales the } \\
\text { replacement rate between } 0 \text { and } \\
1 \text { (i.e. } 0.75 \text { means that that } 75 \% \\
\text { of the income prior to } \\
\text { unemployment is being } \\
\text { replacement by unemployment } \\
\text { benefits). Years used for each } \\
\text { country: } 2003,2008 \text { and } 2011 .\end{array}$ & $\begin{array}{l}\text { Van Vliet, Olaf \& Koen } \\
\text { Caminada (2012), } \\
\text { 'Unemployment } \\
\text { replacement rates dataset } \\
\text { among } 34 \text { welfare states } \\
\text { 1971-2009: An update, } \\
\text { extension and modification } \\
\text { of Scruggs' Welfare State } \\
\text { Entitlements Data Set', } \\
\text { NEUJOBS Special Report } \\
\text { No. 2, Leiden University }\end{array}$ \\
\hline $\begin{array}{l}\text { Electoral } \\
\text { frationalisation }\end{array}$ & 81 & 76.529 & 8.19055 & 50.6051 & 90.0687 & $\begin{array}{l}\text { Index of electoral } \\
\text { fractionalization of the party } \\
\text { system according to the formula } \\
\text { [F] proposed by Rae (1968). } \\
\text { Years used for each country: } \\
2003,2008 \text { and } 2011 .\end{array}$ & $\begin{array}{l}\text { Klaus Armingeon, Romana } \\
\text { Careja, Laura Knöpfel, } \\
\text { David Weisstanner, Sarah } \\
\text { Engler, Pana-jotis Potolidis, } \\
\text { Marlène Gerber. } 2013 . \\
\text { Comparative Political Data } \\
\text { Set III 1990-2011. Bern: } \\
\text { Institute of Political } \\
\text { Science, University of } \\
\text { Berne. }\end{array}$ \\
\hline $\begin{array}{l}\text { Proportional } \\
\text { representation } \\
\text { dummy }\end{array}$ & 81 & 0.925 & 0.263523 & 0 & 1 & $\begin{array}{l}\text { Proportional Representation? ( } 1 \\
\text { if yes, } 0 \text { if no): " } 1 \text { " if candidates } \\
\text { are elected based on the percent } \\
\text { of votes received by their party } \\
\text { and/or if our sources specifically } \\
\text { call the system "proportional } \\
\text { representation". "0" otherwise. } \\
\text { Years used for each country: } \\
2003,2008 \text { and } 2011 .\end{array}$ & $\begin{array}{l}\text { DPI2012 (2012) Database } \\
\text { of Political Institutions: } \\
\text { Changes and Variable } \\
\text { Definitions. Philip Keefer, } \\
\text { Development Research } \\
\text { Group, The World Bank. }\end{array}$ \\
\hline Total trade & 84 & 113.80 & 65.85811 & 0 & 371.4 & Sum of Export and Import of & Eurostat \\
\hline
\end{tabular}




\begin{tabular}{|c|c|c|c|c|c|c|c|}
\hline Variable & Observations & Mean & Std. Dev. & Minimum & Maximum & Description & Sources \\
\hline (\% of GDP) & & & & & & $\begin{array}{l}\text { Goods and Services, \% of GDP. } \\
\text { Years used for each country: } \\
2003,2008 \text { and } 2013 .\end{array}$ & \\
\hline Industry & 83 & 27.096 & 6.026859 & 12.4 & 40.2 & $\begin{array}{l}\text { Industry employment as \% of } \\
\text { Total Employment }\end{array}$ & European Commission \\
\hline $\begin{array}{l}\text { Immigration bad for } \\
\text { culture }\end{array}$ & 64 & 29.959 & 12.96557 & 7.1 & 68 & $\begin{array}{l}\text { Respondents have to position } \\
\text { themselves on the following } \\
\text { statement: "Country's cultural } \\
\text { life undermined or enriched by } \\
\text { immigrants". They choose a } \\
\text { number between } 0 \text { (Cultural life } \\
\text { undermined) and } 10 \text { (Cultural life } \\
\text { enriched). This variable sums the } \\
\text { share of respondents that have } \\
\text { responded } 0 \text { to } 4 \text { (since } 5 \text { is a } \\
\text { neutral position it is not included } \\
\text { in our "immigration is bad for } \\
\text { culture" variable). Three ESS } \\
\text { waves were used: } 2004,2008 \\
\text { and } 2012 \text {. }\end{array}$ & $\begin{array}{l}\text { European Social Survey, } \\
\text { closest wave preceding the } \\
\text { EP election }\end{array}$ \\
\hline $\begin{array}{l}\text { Employment } \\
\text { Protection Index }\end{array}$ & 61 & 2.6069 & 0.447958 & 1.55839 & 4.09524 & $\begin{array}{l}\text { Strictness of employment } \\
\text { protection - individual and } \\
\text { collective dismissals (regular } \\
\text { contracts). Years used for each } \\
\text { country: 2003, } 2008 \text { and } 2013 .\end{array}$ & $\begin{array}{l}\text { OECD and Avdagic, S. } \\
\text { (2012a), 'EPL Index in } \\
\text { Central and Eastern } \\
\text { Europe, 1990-2009'. UK } \\
\text { Data Archive, Economic } \\
\text { and Social Data Service. } \\
\text { Retrieved } 31 \text { May } 2012\end{array}$ \\
\hline Total Immigration & 78 & 132.237 & 193.341 & 0.967 & 768.975 & $\begin{array}{l}\text { Immigration (1000s). Years used } \\
\text { for each country: 2003, } 2008 \text { and } \\
2012 \text {. }\end{array}$ & Eurostat \\
\hline $\begin{array}{l}\text { Effective number of } \\
\text { parties }\end{array}$ & 81 & 4.784 & 1.705698 & 2.024501 & 10.06917 & $\begin{array}{l}\text { Effective number of parties on } \\
\text { the votes level according to the }\end{array}$ & $\begin{array}{l}\text { Klaus Armingeon, Romana } \\
\text { Careja, Laura Knöpfel, }\end{array}$ \\
\hline
\end{tabular}




\begin{tabular}{|c|c|c|c|c|c|c|c|}
\hline Variable & Observations & Mean & Std. Dev. & Minimum & Maximum & Description & Sources \\
\hline & & & & & & $\begin{array}{l}\text { formula [ } \mathrm{N}_{2} \text { ] pro-posed by Laakso } \\
\text { and Taagepera (1979). Years } \\
\text { used for each country: 2003, } \\
2008 \text { and } 2011 .\end{array}$ & $\begin{array}{l}\text { David Weisstanner, Sarah } \\
\text { Engler, Pana-jotis Potolidis, } \\
\text { Marlène Gerber. } 2013 . \\
\text { Comparative Political Data } \\
\text { Set III 1990-2011. Bern: } \\
\text { Institute of Political } \\
\text { Science, University of } \\
\text { Berne. }\end{array}$ \\
\hline Inequality ratio & 75 & 4.708 & 1.096895 & 3.1 & 7.4 & $\begin{array}{l}\text { Inequality of income distribution, } \\
\text { top to bottom income quintile } \\
\text { share ratio. Years used for each } \\
\text { country: } 2003,2008 \text { and } 2011 .\end{array}$ & Eurostat \\
\hline $\begin{array}{l}\text { Passive Labour } \\
\text { market policies }\end{array}$ & 68 & 0.9007 & 0.679872 & 0.15 & 2.662 & $\begin{array}{l}\text { Spending on passive labour } \\
\text { market policies. Years used for } \\
\text { each country: 2003, } 2008 \text { and } \\
2012 \text {. }\end{array}$ & OECD \\
\hline $\begin{array}{l}\text { Active labour } \\
\text { market policies }\end{array}$ & 65 & 0.4329 & 0.344162 & 0.034 & 1.597 & $\begin{array}{l}\text { Spending on active labour } \\
\text { market policies. Years used for } \\
\text { each country: 2003, } 2008 \text { and } \\
2012 \text {. }\end{array}$ & OECD \\
\hline $\begin{array}{l}\text { OECD } \\
\text { unemployment } \\
\text { benefit rate }\end{array}$ & 71 & 36.360 & 14.56975 & 17.41 & 65.24 & $\begin{array}{l}\text { Net unemployment insurance } \\
\text { and unemployment assistance } \\
\text { benefits for an average worker. } \\
\text { Years used for each country: } \\
2003,2008 \text { and } 2012 \text {. }\end{array}$ & OECD, Tax-Benefit Models \\
\hline
\end{tabular}


Table A2: Robustness to inclusion of additional variables

\begin{tabular}{|c|c|c|c|c|c|c|c|c|}
\hline Column & $(1)$ & $(2)$ & $(3)$ & $(4)$ & $(5)$ & $(6)$ & (7) & $(8)$ \\
\hline Unemployment rate & -0.63 & -0.21 & -0.74 & -0.65 & -0.64 & -0.62 & & \\
\hline Real GDP & -1.22 & -0.95 & -1.32 & & -1.23 & -1.21 & -1.19 & -1.19 \\
\hline Unemployment benefits & $-6.80 * * *$ & $-6.74 * * *$ & $-7.02 * * *$ & $-6.57 * * *$ & $-6.82 * * *$ & $-6.77 * * *$ & $-6.78 * * *$ & $-6.82 * * *$ \\
\hline Electoral fractionalisation & $2.27^{t}$ & 2.28 & 2.19 & 2.08 & 2.26 & $2.28^{\mathrm{t}}$ & $2.25^{t}$ & $2.30^{\mathrm{t}}$ \\
\hline Proportional Representation & $-7.42 *$ & -6.05 & -7.29 & $-9.70 * *$ & $-7.46^{t}$ & $-7.35^{*}$ & $-7.84^{*}$ & $-7.47^{*}$ \\
\hline Total Trade & 0.67 & 1.12 & 0.78 & -0.31 & & & 0.93 & 0.76 \\
\hline Share of industrial employment & $-2.63^{*}$ & $-2.37^{t}$ & $-2.82^{*}$ & $-2.74^{*}$ & $-2.62^{t}$ & $-2.64^{*}$ & $-2.45^{t}$ & $-2.57^{*}$ \\
\hline EPL & 0.80 & 0.10 & 0.63 & 0.84 & 0.83 & 0.77 & 0.82 & 0.81 \\
\hline Total immigration & $2.08^{t}$ & & & & $2.05^{t}$ & $2.10^{t}$ & $2.20^{\mathrm{t}}$ & $2.09^{t}$ \\
\hline Immigration from EU countries & & $2.91^{\mathrm{t}}$ & & & & & & \\
\hline Immigration from non-EU countries & & & $1.94^{*}$ & & & & & \\
\hline Crisis dummy & & & & 0.91 & & & & \\
\hline Immigrant population & & & & 0.80 & & & & \\
\hline Exports & & & & & 0.64 & & & \\
\hline Imports & & & & & & 0.67 & & \\
\hline Youth unemployment & & & & & & & -0.37 & \\
\hline Long term unemployment & & & & & & & & -0.64 \\
\hline Constant & $14.98 * * *$ & $13.37^{* *}$ & $14.71 * * *$ & $17.32 * * *$ & $15.02 * * *$ & $14.96 * * *$ & $15.34 * * *$ & $15.03 * * *$ \\
\hline Observations & 56 & 52 & 51 & 56 & 56 & 56 & 56 & 56 \\
\hline Number of id & 21 & 21 & 21 & 21 & 21 & 21 & 21 & 21 \\
\hline R-squared within model & 0.31 & 0.43 & 0.37 & 0.26 & 0.31 & 0.31 & 0.32 & 0.31 \\
\hline R-squared overall model & 0.44 & 0.39 & 0.43 & 0.44 & 0.44 & 0.44 & 0.43 & 0.43 \\
\hline R-squared between model & 0.45 & 0.36 & 0.41 & 0.44 & 0.45 & 0.45 & 0.43 & 0.44 \\
\hline
\end{tabular}

Note: Robust standard errors clustered by country (not shown for reasons of space, see: ${ }^{* * *} p<0.001,{ }^{* *} p<0.01, * p<0.05,{ }^{t} p<0.1$ ). All independent variables are standardised around mean 0 with standard deviation of 1 . Thus the coefficients are directly comparable: they show the effect on far right support of a 1 standard deviation change in the independent variable. 
Table A2: Robustness to inclusion of additional variables (continued)

\begin{tabular}{|c|c|c|c|c|c|c|c|}
\hline Column & (9) & $(10)$ & $(11)$ & $(12)$ & $(13)$ & (14) & (15) \\
\hline Unemployment rate & -1.02 & -0.22 & -1.22 & -1.40 & -0.59 & -0.40 & .14 \\
\hline Real GDP & & & 0.23 & -1.70 & -1.57 & -1.73 & -1.06 \\
\hline Unemployment benefits & $-6.68 * * *$ & $-6.78 * *$ & & & $-5.90 *$ & $-6.00 *$ & $-7.66 * * *$ \\
\hline Electoral fractionalisation & 2.15 & 2.07 & 2.54 & $2.89^{t}$ & $3.16^{\mathrm{t}}$ & $3.11^{\mathrm{t}}$ & -.002 \\
\hline Proportional system & $-7.17^{t}$ & $-6.91^{\mathrm{t}}$ & $-8.87^{*}$ & -5.19 & -9.34 & -9.17 & $-11.92 * *$ \\
\hline Industrial employment & -2.46 & $-3.02 *$ & -1.03 & -2.34 & & & $-2.72^{t}$ \\
\hline EPL & 0.73 & 0.76 & -1.68 & -1.49 & -0.26 & -0.02 & 2.21 \\
\hline Total immigration & $2.04^{\mathrm{t}}$ & $2.36^{t}$ & 0.44 & $1.95^{\mathrm{t}}$ & 1.92 & 1.80 & .848 \\
\hline Total trade (\% GDP) & 0.85 & 0.75 & -0.98 & -2.25 & 1.51 & 1.45 & 1.43 \\
\hline Debt (\% GDP) & 1.32 & & & & & & \\
\hline Deficit (\% GDP) & & 0.36 & & & & & \\
\hline $\begin{array}{l}\text { Spending on active labour market } \\
\text { policies }\end{array}$ & & & 0.77 & & & & \\
\hline $\begin{array}{l}\text { OECD unemployment benefit } \\
\text { replacement rate }\end{array}$ & & & & $-4.56 * *$ & & & \\
\hline $\begin{array}{l}\text { Inequality ratio between top and bottom } \\
\text { quintile }\end{array}$ & & & & & 1.71 & & \\
\hline Gini coefficient & & & & & & 1.45 & \\
\hline $\begin{array}{l}\text { \% who think immigration bad for } \\
\text { country's culture }\end{array}$ & & & & & & & -2.22 \\
\hline Constant & $14.73 * * *$ & $14.67 * * *$ & $15.50 * * *$ & $12.68 * * *$ & $17.14 * * *$ & $16.89 * * *$ & $19.25 * * *$ \\
\hline Observations & 56 & 56 & 45 & 56 & 50 & 49 & 48 \\
\hline Number of countries & 21 & 21 & 20 & 21 & 21 & 21 & 18 \\
\hline R-squared within model & 0.31 & 0.32 & 0.19 & 0.30 & 0.30 & 0.29 & 0.21 \\
\hline R-squared overall model & 0.44 & 0.43 & 0.21 & 0.25 & 0.35 & 0.35 & 0.66 \\
\hline R-squared between model & 0.45 & 0.42 & 0.23 & 0.26 & 0.37 & 0.38 & 0.58 \\
\hline
\end{tabular}

Note: Robust standard errors clustered by country (not shown for reasons of space, see: $*^{* * *} p<0.001,{ }^{* *} p<0.01,{ }^{*} p<0.05,{ }^{t} p<0.1$ ). All independent variables are standardised around mean 0 with standard deviation of 1 . Thus the coefficients are directly comparable: they show the effect on far right support of a 1 standard deviation change in the independent variable. 
Table A3: Regression results for interaction effects

\begin{tabular}{lcc}
\hline Column & $(1)$ & $(2)$ \\
\hline Unemployment rate & $0.79^{* *}$ & $2.10^{* *}$ \\
Real GDP & $(0.281)$ & $(0.809)$ \\
& -0.03 & -0.23 \\
Unemployment benefits & $(0.204)$ & $(0.355)$ \\
& $-23.46^{*}$ & $-39.06^{* *}$ \\
Electoral fractionalisation & $(10.902)$ & $(12.859)$ \\
& $0.32^{* *}$ & $0.36^{*}$ \\
Total immigration & $(0.116)$ & $(0.177)$ \\
& $0.01^{*}$ & $0.02^{*}$ \\
Unemployment rate* Unemployment benefits & $(0.007)$ & $(0.007)$ \\
EPL & $-1.30^{*}$ & 3.92 \\
Unemployment rate*EPL & & $-0.83^{* *}$ \\
\hline Constant & & -8.80 \\
Observations & -5.65 & 58 \\
Number of id & 72 & 22 \\
R-squared within model & 27 & 0.33 \\
R-squared overall model & 0.20 & 0.26 \\
R-squared between model & 0.28 & 0.25 \\
\hline
\end{tabular}

Note: Robust standard errors clustered by country in parentheses; ${ }^{* * *} p<0.001,{ }^{* *} p<0.01,{ }^{*} p<0.05$, ${ }^{t} p<0.1$. The interaction effects' magnitude and significance cannot be evaluated from the table results (see Kam and Franzese, 2007). Note that contrary to other regressions, the variables used in this regression have not been standardised so that interaction effects can be shown for actual values of each variable (note therefore that the immigration data is expressed in 1000 s so values in this variable can be in the 100s). 
Table A4: Results for regression model of table 1, column 10, without including the UK in the sample

\begin{tabular}{|c|c|}
\hline Column & $(1)$ \\
\hline \multirow[t]{2}{*}{ Unemployment rate } & -0.68 \\
\hline & $(0.879)$ \\
\hline \multirow[t]{2}{*}{ Real GDP } & -1.68 \\
\hline & $(1.220)$ \\
\hline \multirow[t]{2}{*}{ Unemployment benefits } & $-7.43 * * *$ \\
\hline & $(1.980)$ \\
\hline \multirow[t]{2}{*}{ Electoral fractionalisation } & $2.45 t$ \\
\hline & $(1.363)$ \\
\hline \multirow[t]{2}{*}{ Immigration } & $2.71^{*}$ \\
\hline & $(1.336)$ \\
\hline \multirow[t]{2}{*}{ Proportional Representation } & $-10.18 * * *$ \\
\hline & $(2.713)$ \\
\hline \multirow[t]{2}{*}{ Total trade (\% GDP) } & 1.01 \\
\hline & $(1.601)$ \\
\hline \multirow[t]{2}{*}{ Share of industry } & $-2.56 t$ \\
\hline & $(1.407)$ \\
\hline \multirow[t]{2}{*}{ EPL } & 0.77 \\
\hline & $(1.385)$ \\
\hline Constant & $17.65^{* * *}$ \\
\hline Year effects & No \\
\hline Country effects & No \\
\hline Observations & 53 \\
\hline Number of countries & 20 \\
\hline R-squared within model & 0.35 \\
\hline R-squared overall model & 0.34 \\
\hline R-squared between model & 0.34 \\
\hline
\end{tabular}


Figure A1: Far right-wing party support, unemployment rate, and EPL (without UK)

Average Marginal Effects of Unemployment rate with $90 \% \mathrm{Cls}$

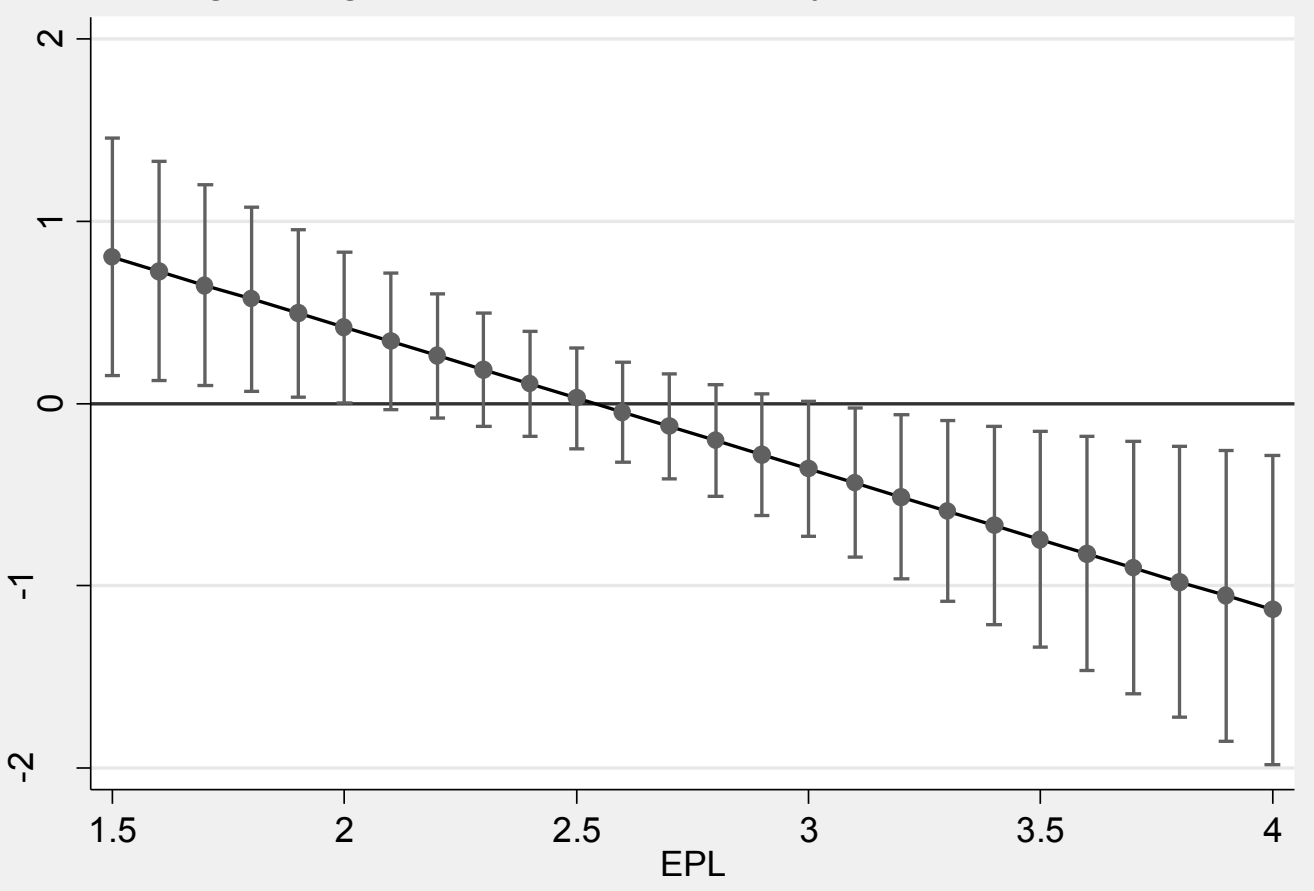

Figure A2: Far right-wing party support, unemployment rate, and unemployment benefits (without UK)

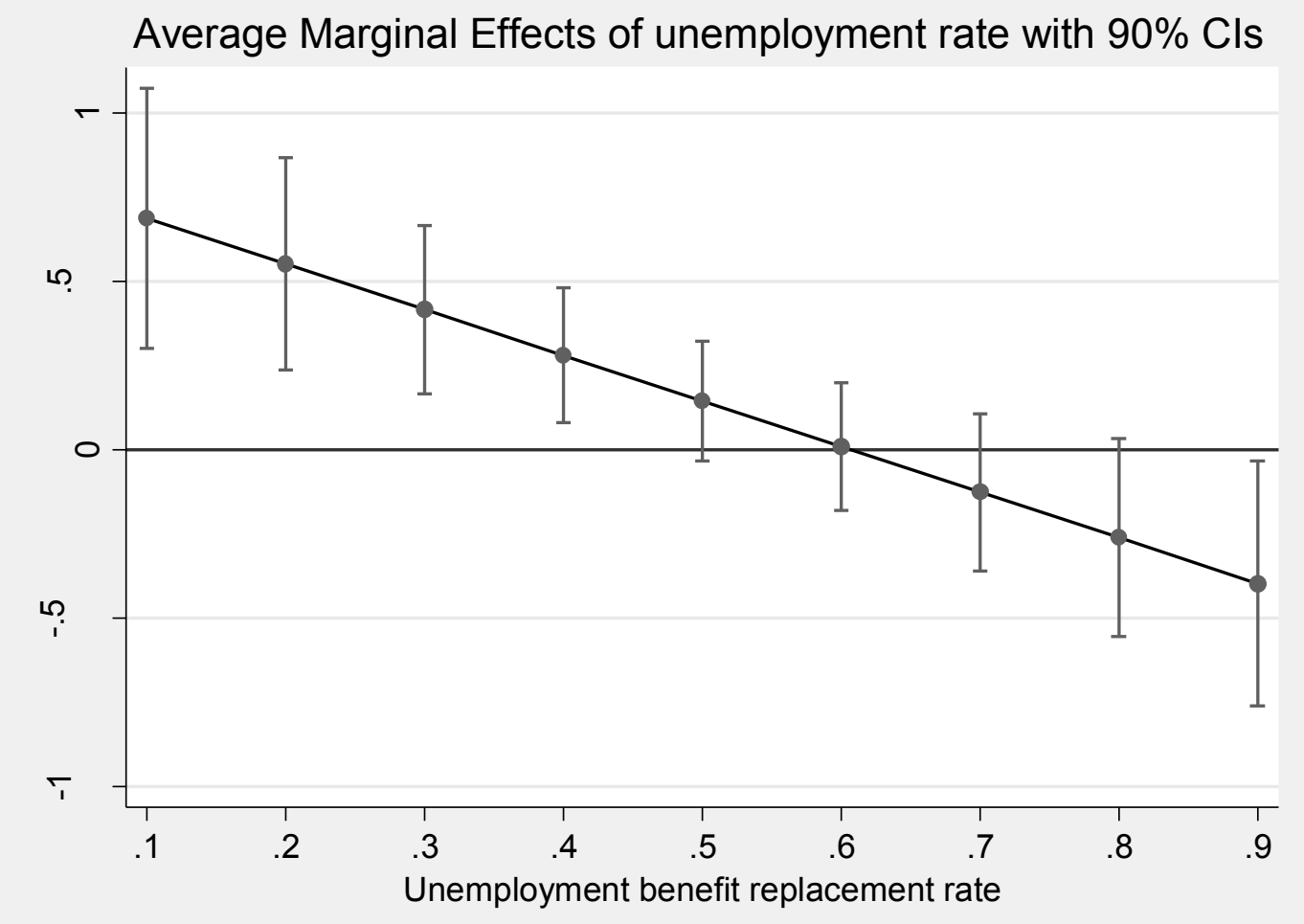


Appendix 2: Sources for coding of far right wing parties in Europe

\begin{tabular}{|c|c|c|}
\hline Country & Far right wing party & Sources \\
\hline Austria & $\begin{array}{l}\text { Austrian Freedom } \\
\text { Party (FPÖ) }\end{array}$ & $\begin{array}{l}\text { Immerzeel, T., et al (2015) Competing with the radical right: Distances between the European radical right } \\
\text { and other parties on typical radical right issues, Party Politics, DOI: } 10.1177 / 1354068814567975\end{array}$ \\
\hline Austria & $\begin{array}{l}\text { Alliance for the Future } \\
\text { of Austria (BZÖ) }\end{array}$ & $\begin{array}{l}\text { Immerzeel, T., et al (2015) Competing with the radical right: Distances between the European radical right } \\
\text { and other parties on typical radical right issues, Party Politics, DOI: } 10.1177 / 1354068814567975\end{array}$ \\
\hline Belgium & Flemish Interest (VB) & $\begin{array}{l}\text { Immerzeel, T., et al (2015) Competing with the radical right: Distances between the European radical right } \\
\text { and other parties on typical radical right issues, Party Politics, DOI: } 10.1177 / 1354068814567975\end{array}$ \\
\hline Bulgaria & $\begin{array}{l}\text { National Union Attack } \\
\text { (ATAKA) }\end{array}$ & $\begin{array}{l}\text { Immerzeel, T., et al (2015) Competing with the radical right: Distances between the European radical right } \\
\text { and other parties on typical radical right issues, Party Politics, DOI: } 10.1177 / 1354068814567975\end{array}$ \\
\hline Croatia & $\begin{array}{l}\text { Croatian Party of } \\
\text { Rights (HSP) }\end{array}$ & $\begin{array}{l}\text { Immerzeel, T., et al (2015) Competing with the radical right: Distances between the European radical right } \\
\text { and other parties on typical radical right issues, Party Politics, DOI: } 10.1177 / 1354068814567975\end{array}$ \\
\hline Cyprus & $\begin{array}{l}\text { National Popular Front } \\
\text { (ELAM) }\end{array}$ & $\begin{array}{l}\text { Katsourides, Y. (2013) 'Determinants of Extreme Right Reappearance in Cyprus: The National Popular Front } \\
\text { (ELAM), Golden Dawn's Sister Party', South European Society and Politics, 18:4 }\end{array}$ \\
\hline $\begin{array}{l}\text { Czech } \\
\text { Republic }\end{array}$ & $\begin{array}{l}\text { Workers' Party of } \\
\text { Social Justice (DSSS) }\end{array}$ & $\begin{array}{l}\text { Mareš, M. (2012) Right-Wing Extremism in the Czech Republic, International Policy Analysis, Friedrich } \\
\text { Ebert Stiftung }\end{array}$ \\
\hline Denmark & $\begin{array}{l}\text { Danish People's Party } \\
\text { (DF) }\end{array}$ & $\begin{array}{l}\text { Immerzeel, T., et al (2015) Competing with the radical right: Distances between the European radical right } \\
\text { and other parties on typical radical right issues, Party Politics, DOI: } 10.1177 / 1354068814567975\end{array}$ \\
\hline Estonia & $\begin{array}{l}\text { Estonian } \\
\text { Independence Party } \\
\text { (EIP) }\end{array}$ & $\begin{array}{l}\text { Immerzeel, T., et al (2015) Competing with the radical right: Distances between the European radical right } \\
\text { and other parties on typical radical right issues, Party Politics, DOI: } 10.1177 / 1354068814567975\end{array}$ \\
\hline Finland & True Finns (PS) & Immerzeel, T., et al (2015) Competing with the radical right: Distances between the European radical right \\
\hline
\end{tabular}




\begin{tabular}{|c|c|c|}
\hline Country & Far right wing party & Sources \\
\hline & & and other parties on typical radical right issues, Party Politics, DOI: 10.1177/1354068814567975 \\
\hline France & National Front (FN) & $\begin{array}{l}\text { Immerzeel, T., et al (2015) Competing with the radical right: Distances between the European radical right } \\
\text { and other parties on typical radical right issues, Party Politics, DOI: } 10.1177 / 1354068814567975\end{array}$ \\
\hline Germany NPD & $\begin{array}{l}\text { National Democratic } \\
\text { Party of Germany } \\
\text { (NPD) }\end{array}$ & $\begin{array}{l}\text { Immerzeel, T., et al (2015) Competing with the radical right: Distances between the European radical right } \\
\text { and other parties on typical radical right issues, Party Politics, DOI: } 10.1177 / 1354068814567975\end{array}$ \\
\hline Germany & The Republicans (REP) & $\begin{array}{l}\text { Immerzeel, T., et al (2015) Competing with the radical right: Distances between the European radical right } \\
\text { and other parties on typical radical right issues, Party Politics, DOI: } 10.1177 / 1354068814567975\end{array}$ \\
\hline Greece & Golden Dawn (GD) & $\begin{array}{l}\text { Vasilopoulou, S. \& Halikiopoulou, D. (2015) The Golden Dawn's Nationalist Solution: Explaining the Rise of } \\
\text { the Far Right in Greece, New York: Palgrave. ISBN } 9781137487124 .\end{array}$ \\
\hline Greece & $\begin{array}{l}\text { Popular Orthodox } \\
\text { Rally (LAOS) }\end{array}$ & $\begin{array}{l}\text { Immerzeel, T., et al (2015) Competing with the radical right: Distances between the European radical right } \\
\text { and other parties on typical radical right issues, Party Politics, DOI: } 10.1177 / 1354068814567975\end{array}$ \\
\hline Greece & $\begin{array}{l}\text { Independent Greeks } \\
\text { (ANEL) }\end{array}$ & $\begin{array}{l}\text { Vasilopoulou, S. \& Halikiopoulou, D. (2015) The Golden Dawn's Nationalist Solution: Explaining the Rise of } \\
\text { the Far Right in Greece, New York: Palgrave. ISBN } 9781137487124 .\end{array}$ \\
\hline Hungary & $\begin{array}{l}\text { Movement for a } \\
\text { better Hungary } \\
\text { (Jobbik) }\end{array}$ & $\begin{array}{l}\text { Immerzeel, T., et al (2015) Competing with the radical right: Distances between the European radical right } \\
\text { and other parties on typical radical right issues, Party Politics, DOI: } 10.1177 / 1354068814567975\end{array}$ \\
\hline Ireland & N/A & \\
\hline Italy (LN) & Northern League (LN) & $\begin{array}{l}\text { Immerzeel, T., et al (2015) Competing with the radical right: Distances between the European radical right } \\
\text { and other parties on typical radical right issues, Party Politics, DOI: } 10.1177 / 1354068814567975\end{array}$ \\
\hline Latvia & National Alliance (NA) & $\begin{array}{l}\text { Vasilopoulou, S. (2011) 'European Integration and the Radical } \\
\text { Right: Three Patterns of Opposition', Government and Opposition } 46 \text { (2): 223-244 }\end{array}$ \\
\hline Lithuania & Order and Justice & Rydgren, J. (ed). (2013) Class Politics and the Radical Right, Oxon: Routledge \\
\hline
\end{tabular}




\begin{tabular}{|c|c|c|}
\hline Country & Far right wing party & Sources \\
\hline & party (TT) & \\
\hline Luxemburg & $\begin{array}{l}\text { National Movement } \\
\text { (NB) }\end{array}$ & $\begin{array}{l}\text { Lubbers, M., Gijsberts, M. and Scheepers, P. (2002), 'Extreme right-wing voting in Western Europe' } \\
\text { European Journal of Political Research 41: } 345-378\end{array}$ \\
\hline Malta & Imperium Europa (IE) & $\begin{array}{l}\text { Minkenberg, M. and Perrineau, P (2004) The Radical Right in the European Elections 2004, International } \\
\text { Political Science Review, 28(1): 29-55; Falzon, M.A and Micallef, .M (2012) Rights, Roots and Routes: Local } \\
\text { and transnational Contexts of Extreme Right Movements in Contemporary Malta in Mammone, A., Godin, } \\
\text { E. and Jenkins, B. (Eds) (2012) Mapping the Extreme Right in Contemporary Europe: From Local to } \\
\text { Transnational, Oxon: Routledge }\end{array}$ \\
\hline Netherlands & $\begin{array}{l}\text { Party for Freedom } \\
\text { (PVV) }\end{array}$ & $\begin{array}{l}\text { Immerzeel, T., et al (2015) Competing with the radical right: Distances between the European radical right } \\
\text { and other parties on typical radical right issues, Party Politics, DOI: } 10.1177 / 1354068814567975\end{array}$ \\
\hline Netherlands & List Pim Fortuyn (LPF) & $\begin{array}{l}\text { Harrison, S. and Bruter, M. (2011), Mapping Extreme Right Ideology: An Empirical Geography of the } \\
\text { European Extreme Right', Basingstoke: Palgrave Macmillan }\end{array}$ \\
\hline Poland & $\begin{array}{l}\text { Law and Justice Party } \\
\text { (Pis) }\end{array}$ & $\begin{array}{l}\text { Pankowski, R., (2010) The Populist Radical Right in Poland: The Patriots, Oxon: Routledge; Harrison, S. and } \\
\text { Bruter, M. (2011), Mapping Extreme Right Ideology: An Empirical Geography of the European Extreme } \\
\text { Right', Basingstoke: Palgrave Macmillan; Pankowski, R and Kormak, M., (2013) 'Radical Nationalism in } \\
\text { Poland: From Theory to Practice' In R. Melzer \& Serafin, S. (Eds.), Right-wing extremism in Europe: } \\
\text { Counter-strategies and Labor-Market Oriented Exit Strategies. Friedrich Ebert Foundation }\end{array}$ \\
\hline Poland & $\begin{array}{l}\text { Congress of the New } \\
\text { Right (KPN) }\end{array}$ & $\begin{array}{l}\text { Harrison, S. and Bruter, M. (2011), Mapping Extreme Right Ideology: An Empirical Geography of the } \\
\text { European Extreme Right', Basingstoke: Palgrave Macmillan }\end{array}$ \\
\hline Poland & $\begin{array}{l}\text { League of Polish } \\
\text { Families (LPR) }\end{array}$ & $\begin{array}{l}\text { Harrison, S. and Bruter, M. (2011), Mapping Extreme Right Ideology: An Empirical Geography of the } \\
\text { European Extreme Right', Basingstoke: Palgrave Macmillan; Immerzeel, T., et al (2015) Competing with the } \\
\text { radical right: Distances between the European radical right and other parties on typical radical right issues, } \\
\text { Party Politics, DOI: } 10.1177 / 1354068814567975\end{array}$ \\
\hline Portugal & $\begin{array}{l}\text { National Renovator } \\
\text { Party (PNR) }\end{array}$ & $\begin{array}{l}\text { Immerzeel, T., et al (2015) Competing with the radical right: Distances between the European radical right } \\
\text { and other parties on typical radical right issues, Party Politics, DOI: } 10.1177 / 1354068814567975\end{array}$ \\
\hline
\end{tabular}




\begin{tabular}{|l|l|l|}
\hline Country & Far right wing party & \multicolumn{1}{c|}{ Sources } \\
\hline Romania & $\begin{array}{l}\text { Greater Romanian } \\
\text { Party (PRM) }\end{array}$ & $\begin{array}{l}\text { Immerzeel, T., et al (2015) Competing with the radical right: Distances between the European radical right } \\
\text { and other parties on typical radical right issues, Party Politics, DOI: 10.1177/1354068814567975 }\end{array}$ \\
\hline Slovakia & $\begin{array}{l}\text { Slovak National Party } \\
\text { (SNS) }\end{array}$ & $\begin{array}{l}\text { Immerzeel, T., et al (2015) Competing with the radical right: Distances between the European radical right } \\
\text { and other parties on typical radical right issues, Party Politics, DOI: 10.1177/1354068814567975 }\end{array}$ \\
\hline Slovakia & $\begin{array}{l}\text { People's Party-Our } \\
\text { Slovakia (L'SNS) }\end{array}$ & $\begin{array}{l}\text { Pytlas, B. (2013) 'Radical-right narratives in Slovakia and Hungary: historical legacies, mythic overlaying and } \\
\text { contemporary politics', Patterns of Prejudice, 47(2): 162-183 }\end{array}$ \\
\hline Spain & $\begin{array}{l}\text { Slovenian National } \\
\text { Party (SNS) }\end{array}$ & $\begin{array}{l}\text { Immerzeel, T., et al (2015) Competing with the radical right: Distances between the European radical right } \\
\text { and other parties on typical radical right issues, Party Politics, DOI: 10.1177/1354068814567975 }\end{array}$ \\
\hline Sweden & $\begin{array}{l}\text { National Democracy } \\
\text { (DN) }\end{array}$ & $\begin{array}{l}\text { Ellwood, S. (1995). The extreme right in Spain. In L. Cheles, Ferguson, R. and Vaughan, M. (eds.), The } \\
\text { extreme right in western and eastern Europe. London, New York: Longman. }\end{array}$ \\
\hline UK & $\begin{array}{l}\text { Switish National Party } \\
\text { (BNP) }\end{array}$ & $\begin{array}{l}\text { Immerzeel, T., et al (2015) Competing with the radical right: Distances between the European radical right } \\
\text { and other parties on typical radical right issues, Party Politics, DOI: 10.1177/1354068814567975 }\end{array}$ \\
\hline UK & $\begin{array}{l}\text { United Kingdom } \\
\text { Independence Party } \\
\text { (UKIP) }\end{array}$ & $\begin{array}{l}\text { Immerzeel, T., et al (2015) Competing with the radical right: Distances between the European radical right } \\
\text { and other parties on typical radical right issues, Party Politics, DOI: 10.1177/1354068814567975 }\end{array}$ \\
\hline
\end{tabular}

